\title{
Volcano-hydrothermal system of Ebeko volcano, Paramushir, Kuril Islands: Geochemistry and solute fluxes of magmatic chlorine and sulfur
}

\author{
Elena Kalacheva a ${ }^{\text {, Yuri Taran }}{ }^{\mathrm{b}, *}$, Tatiana Kotenko ${ }^{\mathrm{a}}$, Keiko Hattori ${ }^{\mathrm{c}}$, Leonid Kotenko ${ }^{\mathrm{a}}$, Gabriela Solis-Pichardo ${ }^{\mathrm{d}}$ \\ a Institute of Volcanology and Seismology, FED RAS, Petropavlovsk-Kamchatsky 683006, Russia \\ b Institute of Geophysics, Universidad Nacional Autónoma de México, México City 04510, México \\ c Department of Earth Sciences, University of Ottawa, ON K1N 6N5, Canada \\ d Institute of Geology, Universidad Nacional Autónoma de México, México City 04510, México
}

\section{A R T I C L E I N F O}

\section{Article history:}

Received 23 August 2015

Accepted 7 November 2015

Available online 17 November 2015

\section{Keywords:}

Volcano-hydrothermal system

Geochemistry

Solute fluxes

Kuril Islands

\begin{abstract}
A B S T R A C T
Ebeko volcano at the northern part of Paramushir Island in the Kuril island arc produces frequent phreatic eruptions and relatively strong fumarolic activity at the summit area $1000 \mathrm{~m}$ above sea level (asl). The fumaroles are characterized by low-temperature, $\mathrm{HCl}$ - and S-rich gas and numerous hyper-acid pools $(\mathrm{pH}<1)$ without drains. At $\sim 550 \mathrm{~m}$ asl, in the Yurieva stream canyon, many hot (up to $87^{\circ} \mathrm{C}$ ) springs discharge ultra-acidic $(\mathrm{pH} 1-2) \mathrm{SO}_{4}-$ $\mathrm{Cl}$ water into the stream and finally into the Sea of Okhotsk. During quiescent stages of degassing, these fumaroles emit $1000-2000 \mathrm{t} / \mathrm{d}$ of water vapor, $<20 \mathrm{t} / \mathrm{d}$ of $\mathrm{SO}_{2}$ and $<5 \mathrm{t} / \mathrm{d}$ of $\mathrm{HCl}$. The measurement of acidic hot Yurieva springs shows that the flux of $\mathrm{Cl}$ and $\mathrm{S}, 60-80 \mathrm{t} / \mathrm{d}$ each, is independent on the volcanic activity in the last two decades. Such high flux of $\mathrm{Cl}$ is among the highest ever measured in a volcano-hydrothermal system. Oxygen and hydrogen isotopic composition of water and $\mathrm{Cl}$ concentration for Yurieva springs show an excellent positive correlation, indicating a mixing between meteoric water and magmatic vapor. In contrast, volcanic gas condensates of Ebeko fumaroles do not show a simple mixing trend but rather a complicated data suggesting evaporation of the acidic brine. Temperatures calculated from gas compositions and isotope data are similar, ranging from 150 to $250{ }^{\circ} \mathrm{C}$, which is consistent with the presence of a liquid aquifer below the Ebeko fumarolic fields. Saturation indices of non-silicate minerals suggest temperatures ranging from 150 to $200{ }^{\circ} \mathrm{C}$ for Yurieva springs. Trace elements (including REE) and $\mathrm{Sr}$ isotope composition suggest congruent dissolution of the Ebeko volcanic rocks by acidic waters. Waters of Yurieva springs and waters of the summit thermal fields (including volcanic gas condensates) are different in $\mathrm{Cl} / \mathrm{SO}_{4}$ ratios and isotopic compositions, suggesting complicated boiling-condensationmixing processes.
\end{abstract}

(C) 2015 Elsevier B.V. All rights reserved.

\section{Introduction}

Ebeko volcano on Paramushir Island is one of the best studied active volcanoes of the Kurilian Island Arc. Its eruptive history in details has been traced by Melekestsev et al. (1993). Geological structure as well as petrology and geochemistry of the eruptive products of Ebeko has been studied by many authors (Markhinin, 1967; Gorshkov, 1970; Fedorchenko et al., 1989; Avdeiko et al., 1992, and references therein). There were several attempts for measuring the heat output by fumaroles and hydrothermal system of the volcano (Nekhoroshev, 1960; Menyailov et al., 1988; Kotenko and Kotenko, 2006). Menyailov et al. $(1985,1988)$ and Kotenko et al. (2007) reported chemical composition of fumarolic gases during different stages of the volcanic activity. Menyailov et al. $(1985,1988)$ have measured isotopic composition of the volcanic gas condensates and isotopic ratios of noble gases in two Ebeko fumaroles. Geochemistry of thermal waters has

\footnotetext{
* Corresponding author.

E-mail address: yuri.taran@gmail.com (Y. Taran).
}

been studies in Nikitina (1978), Markhinin and Stratula (1977), Fazlullin (1999), Bortnikova et al. (2006) and Kalacheva and Kotenko (2013). Solute discharge by acidic thermal waters of the volcano-hydrothermal system has been measured by Zelenov (1972) and Fazlullin (1999). One of the two deep wells drilled in the vicinity of the volcano found hot water $\left(90^{\circ} \mathrm{C}\right)$. Rychagov et al. (2002) have used core and cuttings from these wells for a detailed mineralogical description of the geological cross-section near Ebeko.

The volcano is attractive for volcanologists and geochemists for several reasons. Frequent phreatic eruptions are hazards to several thousand people living in a small town of Severo-Kurilsk in the vicinity of the volcano (10-12 km from the crater). Secondly, the volcano is characterized by strong fumarolic and hydrothermal activity with abundant manifestations which are easily accessible. A geochemical monitoring program, including systematic sampling of fumarolic gases, was conducted by Igor Menyailov's group in 1960-1980 (e.g., Menyailov et al., 1985, 1988) and the program was partially re-started after almost a 20 year break (Kotenko et al., 2007, 2012; Bortnikova et al., 2006; Kalacheva and Kotenko, 2013; Kotenko and 
Kotenko, 2006). And finally, since the very early stage of the studies of the volcano, it was discovered that unprecedent amounts of solutes are discharged by ultra-acid thermal waters on the western slope of the volcano to the Sea of Okhotsk (Zelenov, 1972; Nikitina, 1978; Fazlullin, 1999). According to Zelenov (1972) and Markhinin and Stratula (1977), the fluxes of chloride( $>200 \mathrm{t} / \mathrm{d})$ and sulfate (>600 t/d) measured in 1960 are comparable with or even higher than those from high-temperature fumaroles in some quiescently degassing volcanoes in Kamchatka and Kuril Islands, including the Kudryavy, Mutnovsky and many others (e.g., Taran, 2009 and references therein).

Despite close monitoring of the volcanic activity and many publications, the structure, mechanisms and evolution of the volcanohydrothermal system of Ebeko remain to be resolved. Main feature of the hydrothermal activity of Ebeko is the existence of two thermal fields separated in the space, both of which discharge ultra-acid $\mathrm{Cl}-\mathrm{SO}_{4}$ and $\mathrm{SO}_{4}-\mathrm{Cl}$ hot waters (Fig. 1). The summit field (ca. $1000 \mathrm{~m}$ asl) consists of several thermal grounds, low-temperature fumaroles $\left(<120^{\circ} \mathrm{C}\right)$ and near-boiling hyper-acid pools with no or weak outflow rates (Fig. 1). The second thermal field, Yurievsloue springs, is located at low elevations, $\sim 550 \mathrm{~m}$ asl down to $280 \mathrm{~m}$ asl, on the western slope of Ebeko volcano in the canyon of Yurieva River (Fig. 1b). These Yurievskiye springs transport a very high amount of dissolved matter into the sea. It is not understood how these two thermal fields are connected and interacted although there were attempts to build a general conceptual model of the entire system (Nikitina, 1978; Kalacheva and Kotenko, 2013). A part of this question lies the origin of high to very high $\mathrm{HCl}$ (up to $0.3 \mathrm{~mol} \%$ ) in low-temperature fumarolic gases of Ebeko because high $\mathrm{HCl}$ is a common feature of high-temperature fumarolic gases of arc volcanoes.

a
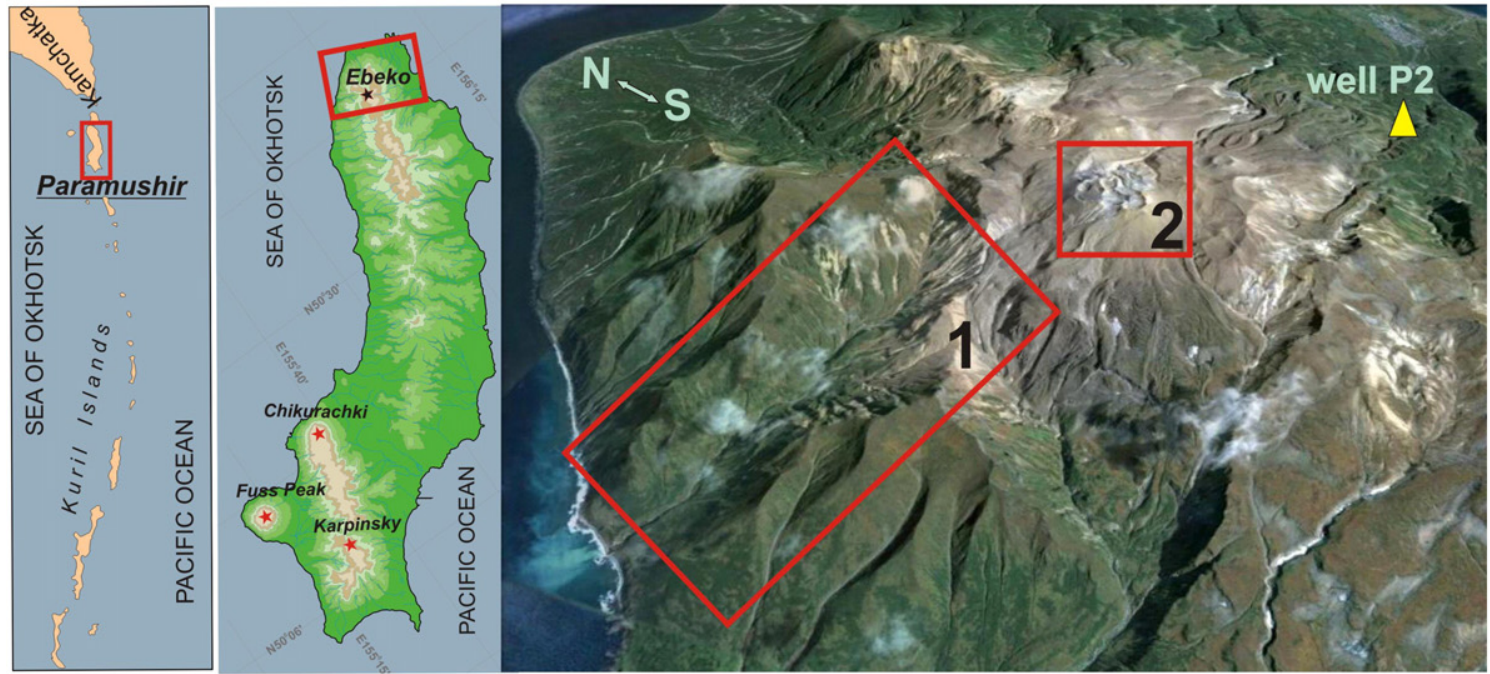

b
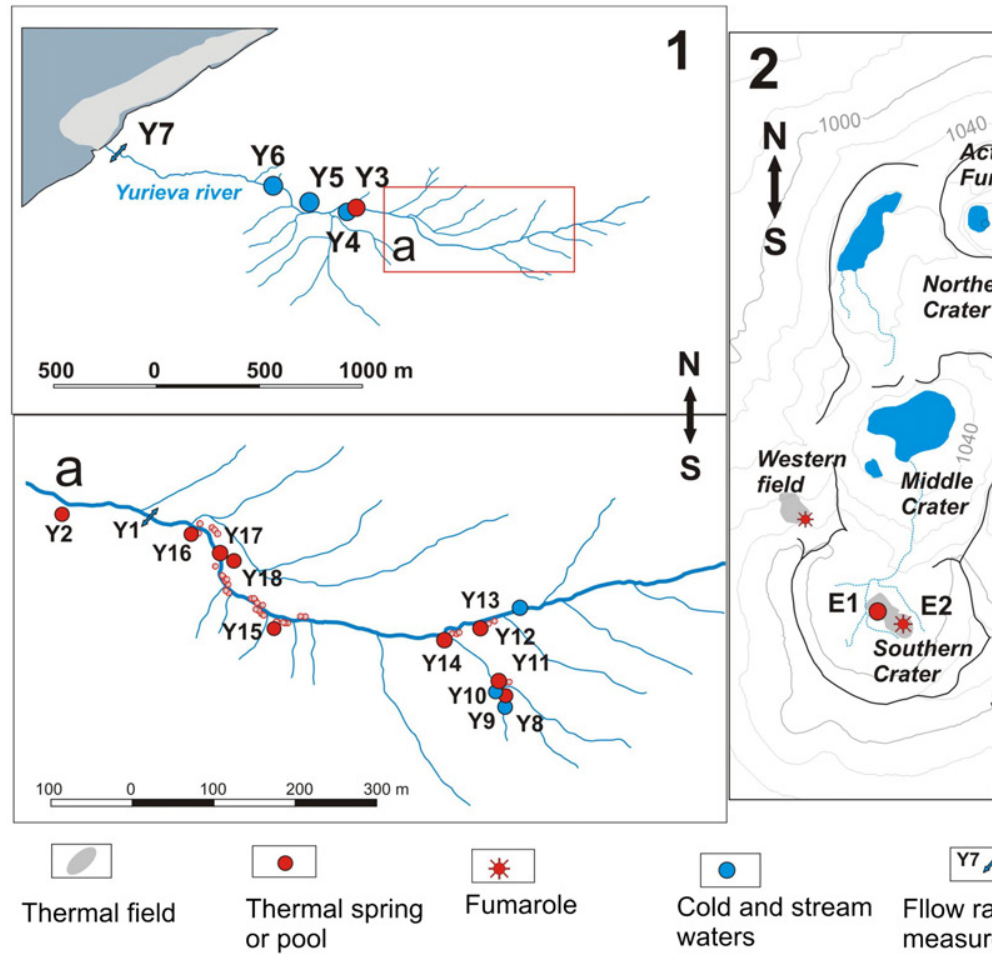

Fllow rate measurement

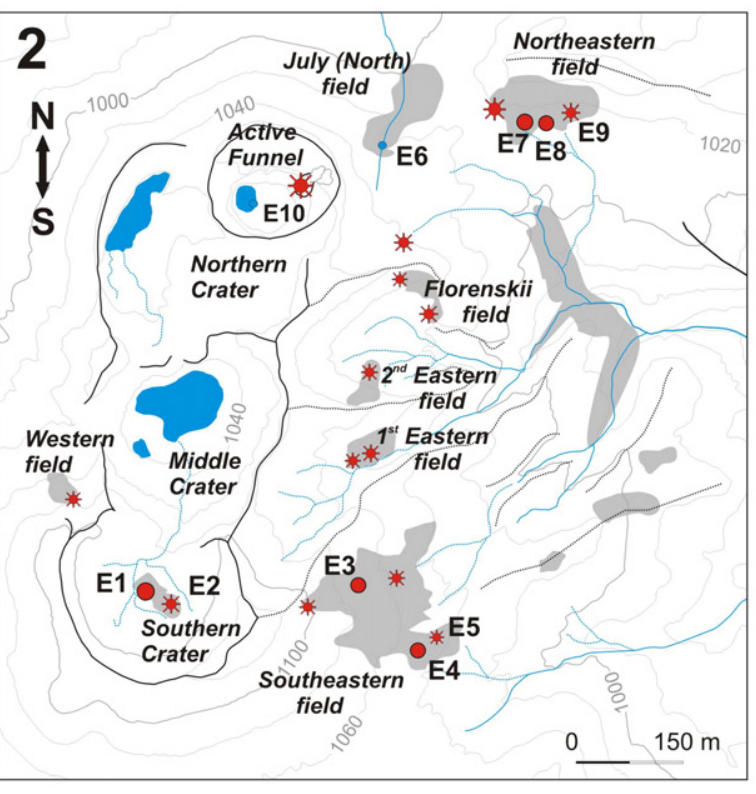

waters

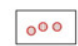

$\begin{array}{ll}\text { Hot springs } & \text { Discolored } \\ \text { in the sea }\end{array}$

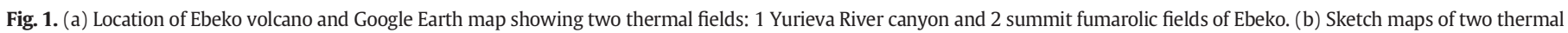
fields: 1 Yurieva River canyon and 2 Ebeko thermal field. 
In this paper we report data on water and gas compositions of samples obtained during the 2014 field season and compare partially published data from 2005, 2010 and 2012 field campaigns. Our results include major and trace elements in waters, the first documentation of the water isotopic composition of Yurievskie springs and Ebeko pools. A limited data set includes the first report of sulfur and oxygen isotopic composition of dissolved sulfate and ${ }^{87} \mathrm{Sr} /{ }^{86} \mathrm{Sr}$ for dissolved $\mathrm{Sr}$ for Yurievskie springs. We have also measured outflow rates for fumarolic gases and the hydrothermal flux of solutes at the mouth of Yurieva River. The data allowed the re-evaluation of the thermal capacity of the system as well as the solute fluxes. We compare our results with the data of previous studies and discuss the evolution of the system and a possible temporal relationship of water chemistry with volcanic eruptions. Geothermometry based on gas compositions and saturation indices for non-silicate minerals allowed to estimate deep aquifer temperatures and the existence of the two-phase aquifer. We propose that a shallow boiling "brine" is the source for the Cl-rich fumaroles and, possibly, for the ultra-acid Yurievskie springs. The high $\mathrm{Cl}$ and $\mathrm{S}$ fluxes from volcano-hydrothermal systems are discussed in terms of the volatile recycling in subduction zones (Taran, 2009; Shinohara, 2013).

\section{Ebeko volcano, phreatic and fumarolic activity}

The Ebeko volcano $\left(50^{\circ} 41^{\prime} \mathrm{N}, 156^{\circ} 01^{\prime} \mathrm{E}\right)$ is located at the northern part of Paramushir Island, at the north of Vernadsky Ridge (Fig. 1a, b) and composed of several Quaternary volcanic cones. The Neogene volcano-clastic basement occurs below 200 m asl (Sergeev, 1966; Gorshkov, 1970; Melekestsev et al., 1993). The post-glacial cone of Ebeko is composed by lava flows and pyroclastics of andesitic composition. The summit is represented by three craters: Northern, Middle and Southern (Fig. 1). The modern phreatic and fumarolic activity of Ebeko started after a strong explosive phreatic-magmatic eruption from the Middle crater in 1934-1935 (Gorshkov, 1970; Melekestsev et al., 1993) which ejected about $10^{6} \mathrm{t}$ of andesitic ash and bombs. Three phreatic eruptions in 1967-1971 in the Northern crater were preceded by a short episode of increasing temperature of fumaroles (Menyailov et al., 1985). In October 1987, after 16 years of moderate low-temperature fumarolic activity, a new phreatic eruption started in the Northern crater lasting 3 months involving 5-6 daily gas-ash explosions (Menyailov et al., 1988). In February 1989, a longest historic phreatic activity started at a funnel formed in 1967 in the Northern crater and produced a new vent on the eastern slope. The activity ceased in April 1989, but in January 1991 several episodes of gas emission combined with ash ejecta were observed (Menyailov et al., 1992). A week lasting event in March 1998 involved a series of gas-ash explosions accompanied by the formation of new fumaroles and increasing fumarolic temperature at the SE field reaching $460{ }^{\circ} \mathrm{C}$ (Fazlullin, 1999). The most recent phreatic activity with many evens took place in 2005-2011 (Kotenko et al., 2007, 2012).

Menyailov et al. $(1985,1988)$ monitored the fumarolic activity of Ebeko in 1960-1980 and noted changes in the activities of different groups of fumaroles before and after phreatic eruptions. They reported that the gas composition was stable, "steady state", between eruptions within a group, but differs between groups. According to Menyailov et al. $(1985,1988)$, fumarolic activity in Ebeko is stable at low temperatures (usually, $<120{ }^{\circ} \mathrm{C}$ ) between eruptions, but sharp changes occur shortly before and after phreatic events. They also noted significant a $\mathrm{SO}_{2}$ proportion in gases with $\mathrm{SO}_{2} / \mathrm{H}_{2} \mathrm{~S}$ between 1 and 10 , and high concentrations of $\mathrm{HCl}$ (up to $0.3 \mathrm{~mol} \%$ ). Another notable feature of the thermal fields is the presence of numerous drainless pools or low-discharge springs, and many of them are boiling with concentrated hyper-acid $\mathrm{Cl}$ $\mathrm{SO}_{4}$-type water. Among them there was a near boiling spring Belyi Klyuch with a low discharge and variable salinity from several to $100 \mathrm{~g} / \mathrm{L}$ of water with $\mathrm{pH} \sim 0$ and $\mathrm{Cl}$ to $80 \mathrm{~g} / \mathrm{L}$ (Markhinin and Stratula, 1977). The spring is no longer present.

\section{Yurievskie springs}

The Yurievskie hot springs have been described in detail by Fazlullin (1999). He has mapped 50 thermal manifestations along the Yurieva River canyon and reported the chemical compositions of these thermal waters obtained during the 1984, 1987 and 1988 field campaigns. The Yurieva River canyonlies $\sim 1 \mathrm{~km}$ from the Ebeko craters on the NE slope of Ebeko (Fig. 1a and b). The hydrothermal activity along the canyon begins at $580 \mathrm{~m}$ asl and continuous down to $280 \mathrm{~m}$ asl. Many vents discharge acidic hot water (with the highest temperature up to $87^{\circ} \mathrm{C}$ ) into the river. The total river length is about $5 \mathrm{~km}$, it flows into the Sea of Okhotsk and forms a $3 \mathrm{~km}$ long discolored plume in the sea (Fig. 1b). The composition of Yurievskie springs was first reported by Ivanov (1961) and subsequently studies on different aspects of the hydrochemistry and the solute fluxes of the springs and the river were carried out by Sidorov (1965), Zelenov (1972), Markhinin and Stratula (1977), Nikitina (1978), Fazlullin (1999), Bortnikova et al. (2006) and Kalacheva and Kotenko (2013).

\section{Methods}

Volcanic gas samples were collected using a Ti sampling tube and Giggenbach bottles filled with $4 \mathrm{~N} \mathrm{NaOH}$ solution. Condensates of volcanic vapor were collected using bubblers cooled with snow. Gas samples from Giggenbach bottles were analyzed following the method described by Giggenbach and Goguel (1989). Condensate samples were used for hydrogen and oxygen isotope analysis.

Water samples were filtrated through $0.45 \mu \mathrm{m}$ filters and collected in plastic bottles. Temperature $\left( \pm 0.1^{\circ} \mathrm{C}\right), \mathrm{pH}$ ( \pm 0.05 units) and conductivity $( \pm 2 \%)$ were measured on site by an Orion multimeter. Samples for cation analyses were acidified with ultra-pure nitric acid. Concentrations of major dissolved species ( $\mathrm{Na}, \mathrm{K}, \mathrm{Ca}, \mathrm{Mg}, \mathrm{Cl}, \mathrm{SO}_{4}$ ) were determined using ionic chromatography. Total $\mathrm{SiO}_{2}$ and $\mathrm{B}$ were determined by colorimetric method using ammonium molybdate (Giggenbach and Goguel, 1989) and carminic acid, respectively. The analytical errors are usually less than $5 \%$.

Concentrations of trace cations were determined by ICP-MS (Agilent $7500 \mathrm{CE}$ ). All determinations were performed with the external standard calibration method, using Re and In as internal standards. The accuracy of the results ( $\pm 5 \%$ ) was obtained by analyzing certified reference materials (NRCSLR-4, SPS-SW1 and NIST1643e). The water samples were analyzed for their oxygen and hydrogen isotopic composition, using "Los Gatos" IR spectrometer. The isotope ratios are expressed in permil vs V-SMOW. The uncertainties are $\pm 0.2 \%$ 。 for $\delta^{18} \mathrm{O}$ and $\pm 1 \%$ for $\delta \mathrm{D}$ (one standard deviation).

For determination of $\delta^{18} \mathrm{O}$ for dissolved sulfate, barite was precipitated in the field from thermal waters. The sample barite and a reference barite, NBS-127, were weighed into pure Ag capsule, and placed in Rapid OXY Cube elemental analyzer, manufactured by Elementar, Germany. The air in the sample was purged and filled by He, and the sample was heated at $1450^{\circ} \mathrm{C}$ in a graphite crucible in the pyrolysis reactor. CO gas released from the sample was carried by He gas to Thermo-Finnigan Delta Plus XP gas-source mass spectrometer for isotope ratio measurements. $87 \mathrm{Sr} / 86 \mathrm{Sr}$ in waters was analyzed in LUGISUNAM. Details of the Sr isotope determination can be find in Schaaf et al. (2005).

The stream flow rate of the Yurieva River was measured after choosing an appropriate gauging-station site by the float method with two cross-sections of the measured depth with a distance of $5 \mathrm{~m}$. We estimate the accuracy of the flow rate determination for the Yurieva River as $\sim 20 \%$ using 5 independent flow rate measurements. The flow rate of fumaroles was measured by the Pitot tube method with the accuracy $\sim 20 \%$. 


\section{Results and discussion}

\subsection{Gas geochemistry and equilibria}

The gas analyses from Ebeko fumaroles and the P2 well are shown in Table 2 together with averaged compositions of fumaroles reported by Menyailov et al. $(1985,1988)$. Gases from different parts of the summit thermal field are all water-rich (97-99 mol\%) and show varying contents of $\mathrm{HCl}$ and total sulfur and ratios of $\mathrm{C} / \mathrm{S}$ and $\mathrm{H}_{2} \mathrm{~S}$ / $\mathrm{SO}_{2}$ in time and space. Generally, the NE fumaroles are lower in $\mathrm{HCl}$ than fumaroles from the SE field. A common feature for all fumarolic gases of Ebeko is low concentrations of $\mathrm{H}_{2}$ and $\mathrm{CO}$ and correspondingly, very low ratios $\mathrm{H}_{2} / \mathrm{H}_{2} \mathrm{O}$ and $\mathrm{CO} / \mathrm{CO}_{2}$ (on average, $10^{-6}$ and $10^{-7}$, respectively). Methane concentrations are also low, several ppmV in dry gas.

Menyailov et al. (1985) reported $\sim 5$ ppm He in dry gas (recalculated from $\mathrm{He} / \mathrm{Ar}$ and $\mathrm{N}_{2} / \mathrm{Ar}$ ) and ${ }^{3} \mathrm{He} /{ }^{4} \mathrm{He}=6.1 \mathrm{Ra}$ in a fumarole from the NE field with $\mathrm{He} / \mathrm{Ne}=12\left(\mathrm{Ra}\right.$ is air ratio of $\left.1.39 \times 10^{-6}\right)$. It gives $\mathrm{C} /{ }^{3} \mathrm{He} \approx 2.4 \times 10^{10}$-a typical arc value (Hilton et al., 2002). Well P2 contains high He concentration (70 ppm) with ${ }^{3} \mathrm{He} /{ }^{4} \mathrm{He}=6.4 \mathrm{Ra}$ with $\mathrm{He} /$ $\mathrm{Ne}=66$ (Rozhkov and Verkhovsky, 1990; Taran, 2009). Since P2 water contains high bicarbonate concentration ( $2800 \mathrm{ppm}$, Table 2$)$ and low gas content $(\sim 1 \mathrm{mmol} / \mathrm{mol}$, Table 1$), \mathrm{C} /{ }^{3} \mathrm{He}$ ratio using the total $\mathrm{C}$ $\left(\mathrm{CO}_{2}\right.$ (gas) $+\mathrm{HCO}_{3}^{-}$(aq) $+\mathrm{CO}_{2}$ (aq) (Taran, 2005, 2009) is calculated to be $2 \times 10^{10}$, which is similar to the ratios of other fumarolic gases.

The $\mathrm{N}_{2}-\mathrm{Ar}-\mathrm{He}$ systematics for Ebeko gases is shown in Fig. 2. Almost all data points are plotted between ASW (air saturated water) and Air lines, indicating that gases are contaminated by either air during the sampling and/or analysis. Some samples after "extracting air" still have $\mathrm{N}_{2} / \mathrm{Ar}$ ratios close to that of air. The main reason may be the consuming of the air oxygen for oxidation of H2S during sampling and storing. It is also possible that air dissolved in meteoric water may have mixed with the deep vapor with an excess on $\mathrm{N}_{2}$. Only two fumaroles show excess $\mathrm{N}_{2}$, as well as the gas from well P2 $\left(\mathrm{N}_{2} / \mathrm{Ar}=150\right)$.

All fumaroles of Ebeko have record low temperatures at present $\left(<120{ }^{\circ} \mathrm{C}\right)$, but the temperatures varied from $100{ }^{\circ} \mathrm{C}$ to $147^{\circ} \mathrm{Cin}$ July after the 2005 phreatic eruption (Kotenko et al., 2007). Nevertheless, all fumaroles discharge high in $\mathrm{SO}_{2}$ compared to $\mathrm{H}_{2} \mathrm{~S}$ and fumaroles from the SE field are also enriched in $\mathrm{HCl}$. This relatively high $\mathrm{SO}_{2}$ concentrations were also observed in samples collected by Menyailov et al $(1985,1988)$ in 1979-1985 (Table 1). A ternary diagram in Fig. 3 shows relative concentrations of $\mathrm{CO}_{2}, \mathrm{~S}_{\mathrm{t}}$ (total sulfur, $\mathrm{SO}_{2}+\mathrm{H}_{2} \mathrm{~S}$ ) and $\mathrm{HCl}$ for Ebeko fumarolic gases and compares those with the composition of high $\mathrm{HCl}$ gases $\left(>97^{\circ} \mathrm{C}\right.$ ) at Poas volcano (Costa Rica) based on the data reported at the Volcanic Gas workshop in 2003 (Newsletter, 2006. See also Fischer et al., 2015). Relatively high concentrations of $\mathrm{HCl}$ in low-temperature volcanic vapors suggest the presence of boiling acidic brine beneath the fumarolic fields. High concentration of $\mathrm{HCl}$ in fumaroles (up to $0.2 \mathrm{~mol} \%$ of $\mathrm{HCl}$ in fumaroles, $\sim 4 \mathrm{~g} / \mathrm{kg}$ or $>0.1 \mathrm{~mole} / \mathrm{kg}$ of vapor) require partitioning of $\mathrm{HCl}$ from a hightemperature brine with very low $\mathrm{pH}$ and a high-temperature (Simonson and Palmer, 1993; Palmer et al., 2004). The relationship of the concentration of $\mathrm{HCl}$ between vapor and brine is expressed by the equation below:

$\mathrm{K}_{\mathrm{p}}=\mathrm{m}_{\mathrm{v}} /\left(\mathrm{m}_{\mathrm{H}+} \mathrm{m}_{\mathrm{Cl}-} \gamma^{2}\right)$

where $\mathrm{K}_{\mathrm{p}}$ is the partitioning constant, $\mathrm{m}_{\mathrm{v}}$ is molality of $\mathrm{HCl}$ in the vapor

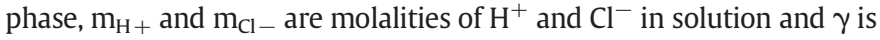
activity coefficient (Simonson and Palmer, 1993; Alvarez et al., 1994). Eq. (1) can be re-written as:

$\mathrm{m}_{\mathrm{v}}=\mathrm{K}_{\mathrm{p}} 10^{-\mathrm{pH}} \mathrm{m}_{\mathrm{Cl}-} \gamma$

Table 1

Coordinates and field data on thermal and cold waters of Paramushir Island sampled in 2014.

\begin{tabular}{|c|c|c|c|c|c|c|c|c|}
\hline Sample site & № $\alpha$ & Latitude $\mathrm{N}$ & Longitude E & $\mathrm{T},{ }^{\circ} \mathrm{C}$ & $\mathrm{pH}_{\text {field }}$ & Eh, mV & $\Omega, \mu \mathrm{S} / \mathrm{cm}$ & $\mathrm{Q}, \mathrm{l} / \mathrm{s}$ \\
\hline \multicolumn{9}{|l|}{ Yurievskie springs } \\
\hline Yurievabelow springs & Y1 & $50^{\circ} 42.42^{\prime}$ & $155^{\circ} 59.10^{\prime}$ & 32.0 & 1.81 & 313 & 11,670 & 630 \\
\hline Thermal spring & Y2 & $50^{\circ} 42.42^{\prime}$ & $155^{\circ} 58.89^{\prime}$ & 17.6 & 4.27 & 158 & 1501 & - \\
\hline Thermal spring & Y3 & $50^{\circ} 42.46^{\prime}$ & $155^{\circ} 58.70^{\prime}$ & 18.0 & 2.33 & 264 & 7230 & $\sim 0.15$ \\
\hline Cold stream & Y4 & $50^{\circ} 42.44^{\prime}$ & $155^{\circ} 58.67^{\prime}$ & 7.2 & 3.67 & 185 & 575 & $\sim 5$ \\
\hline Cold stream & Y5 & $50^{\circ} 42.44^{\prime}$ & $155^{\circ} 58.62^{\prime}$ & 9.1 & 3.48 & 197 & 841 & $\sim 10$ \\
\hline Cold stream & Y6 & $50^{\circ} 42.63^{\prime}$ & $155^{\circ} 58.22^{\prime}$ & 5.3 & 5.70 & 70 & 69 & $\sim 5$ \\
\hline Yurieva mouth & Y7 & $50^{\circ} 42.92^{\prime}$ & $155^{\circ} 56.77^{\prime}$ & 20.0 & 2.18 & 280 & 7870 & 1280 \\
\hline Thermal spring (spring №1) & Y8 & $50^{\circ} 42.10^{\prime}$ & $155^{\circ} 59.87^{\prime}$ & 80.8 & 1.42 & 390 & 20,300 & $\sim 2.5$ \\
\hline Goryachiy stream upper springs & Y9 & $50^{\circ} 42.10^{\prime}$ & $155^{\circ} 59.87^{\prime}$ & 3.7 & 4.05 & 161 & 173 & $\sim 1.5$ \\
\hline Goryachiy stream & Y10 & $50^{\circ} 41.99^{\prime}$ & $155^{\circ} 59.93^{\prime}$ & 60.0 & 1.48 & 357 & 17,960 & $\sim 6$ \\
\hline Thermal spring & Y11 & $50^{\circ} 42.12^{\prime}$ & $155^{\circ} 59.88^{\prime}$ & 68.4 & 1.42 & 375 & 19,050 & $\sim 0.1$ \\
\hline Thermal spring & $\mathrm{Y} 12$ & $50^{\circ} 42.21^{\prime}$ & $155^{\circ} 59.86^{\prime}$ & 34.0 & 2.04 & 302 & 8820 & $\sim 4$ \\
\hline Yurieva upper springs & Y13 & $50^{\circ} 42.22^{\prime}$ & $155^{\circ} 59.87^{\prime}$ & 6.7 & 3.81 & 178 & 201 & 15 \\
\hline Thermal spring & Y14 & $50^{\circ} 42.22^{\prime}$ & $155^{\circ} 59.50^{\prime}$ & 45.1 & 1.73 & 329 & 14,500 & $\sim 3$ \\
\hline Thermal spring & Y15 & $50^{\circ} 42.23^{\prime}$ & $155^{\circ} 59.43^{\prime}$ & 71.2 & 1.51 & 384 & 18,240 & $\sim 2$ \\
\hline Thermal spring & Y16 & $50^{\circ} 42.38^{\prime}$ & $155^{\circ} 59.22^{\prime}$ & 47.5 & 1.89 & 322 & 11,500 & $\sim 5$ \\
\hline Thermal spring & Y17 & $50^{\circ} 42.33^{\prime}$ & $155^{\circ} 59.28^{\prime}$ & 31.8 & 2.23 & 288 & 7510 & $\sim 0.4$ \\
\hline Thermal spring & Y18 & $50^{\circ} 42.32^{\prime}$ & $155^{\circ} 59.31^{\prime}$ & 41.4 & 1.93 & 316 & 11,170 & $\sim 5$ \\
\hline \multicolumn{9}{|l|}{ Ebeko volcano } \\
\hline Pool & E1 & $50^{\circ} 41.20^{\prime}$ & $156^{\circ} 00.83^{\prime}$ & 75.2 & 1.81 & 355 & 6060 & \\
\hline Fumarolic condensate & E2 & $50^{\circ} 41.12^{\prime}$ & $156^{\circ} 00.88^{\prime}$ & 106.0 & 0.60 & 409 & 186,400 & \\
\hline Pool & E3 & $50^{\circ} 41.20^{\prime}$ & $156^{\circ} 01.10^{\prime}$ & 85.1 & 0.25 & 484 & 198,900 & \\
\hline Pool & $\mathrm{E} 4$ & $50^{\circ} 41.15^{\prime}$ & $156^{\circ} 01.16^{\prime}$ & 89.0 & 0.61 & 422 & 59,900 & \\
\hline Fumarolic condensate & E5 & $50^{\circ} 41.16^{\prime}$ & $156^{\circ} 01.18^{\prime}$ & 105.0 & & & & \\
\hline Stream & E6 & $50^{\circ} 41.55^{\prime}$ & $156^{\circ} 01.15^{\prime}$ & 13.4 & 3.28 & 210 & 1132 & \\
\hline Pool & E7 & $50^{\circ} 41.55^{\prime}$ & $156^{\circ} 01.29^{\prime}$ & 72.5 & 1.25 & 380 & 22,300 & \\
\hline Pool & E8 & $50^{\circ} 41.54^{\prime}$ & $156^{\circ} 01.32^{\prime}$ & 80.0 & 1.66 & 361 & 7800 & \\
\hline Fumarolic condensate & E9 & $50^{\circ} 41.54^{\prime}$ & $156^{\circ} 01.35^{\prime}$ & 109.0 & 1.86 & 345 & 8480 & \\
\hline Crater lake & E10 & $50^{\circ} 41.48^{\prime}$ & $156^{\circ} 00.97^{\prime}$ & 16 & 2.72 & 252 & 1663 & \\
\hline Well & $\mathrm{P} 2$ & $50^{\circ} 39.63^{\prime}$ & $156^{\circ} 05.03^{\prime}$ & 70.9 & 7.60 & -40 & 10,350 & \\
\hline
\end{tabular}

$\alpha$ : Numbers correspond to those used in Figures. $\Omega$-conductivity; Q-flow rate. 
Table 2

Gas composition (mol\%) of Ebeko fumaroles and well P2 (recalculated without air).

\begin{tabular}{|c|c|c|c|c|c|c|c|c|c|c|c|c|c|c|}
\hline Sampling site & Year of sampling & $\mathrm{T}^{\circ} \mathrm{C}$ & $\mathrm{H}_{2} \mathrm{O}$ & $\mathrm{H}_{2}$ & $\mathrm{CO}_{2}$ & $\mathrm{CO}$ & $\mathrm{SO}_{2}$ & $\mathrm{H}_{2} \mathrm{~S}$ & $\mathrm{HCl}$ & $\mathrm{HF}$ & $\mathrm{N}_{2}$ & $\mathrm{Ar}$ & $\mathrm{He}$ & $\mathrm{CH}_{4}$ \\
\hline \multicolumn{15}{|l|}{ This work } \\
\hline NE Field & 2003 & 110 & 98.0 & 0.00001 & 1.72 & $1.1 \mathrm{E}-06$ & 0.21 & 0.008 & 0.018 & na & 0.0053 & $1.3 \mathrm{E}-04$ & $1.8 \mathrm{E}-05$ & $5.0 \mathrm{E}-05$ \\
\hline NE Field & 2004 & 110 & 98.7 & 0.000013 & 0.79 & $3.2 \mathrm{E}-06$ & 0.29 & 0.022 & 0.008 & na & 0.0055 & $7.3 \mathrm{E}-05$ & $1.5 \mathrm{E}-06$ & $6.2 \mathrm{E}-06$ \\
\hline NE Field & 2005 & 125 & 97.8 & 0.000009 & 1.22 & $9.0 \mathrm{E}-07$ & 0.65 & 0.033 & 0.047 & na & na & na & $1.5 \mathrm{E}-05$ & $1.3 \mathrm{E}-06$ \\
\hline NE Field & 2012 & 115 & 99.2 & 0.00001 & 0.69 & na & 0.054 & 0.017 & 0.001 & na & 0.024 & 0.0003 & $3.5 \mathrm{E}-6$ & $1.1 \mathrm{E}-5$ \\
\hline July Field & 2005 & 147 & 90.5 & 0.000015 & 2.27 & $4.2 \mathrm{E}-06$ & 3.35 & 0.25 & 2.75 & na & 0.132 & 0.0022 & na & $4.5 \mathrm{E}-06$ \\
\hline July Field & 2011 & 106 & 99.33 & 0.007 & 0.58 & na & 0.034 & 0.025 & 0.005 & na & 0.021 & 0.0002 & $7.4 \mathrm{E}-6$ & $1.5 \mathrm{E}-6$ \\
\hline Active Funnel & 2008 & 105 & 89.59 & 0.00005 & 4.71 & na & 0.41 & 0.14 & 0.38 & na & 3.70 & na & na & na \\
\hline Florensky & 2010 & 117 & 98.32 & 0.00001 & 1.44 & na & 0.018 & 0.19 & 0.03 & na & 0.014 & $2.5 \mathrm{E}-05$ & $2.35 \mathrm{E}-5$ & $6.2 \mathrm{E}-7$ \\
\hline South Crater & 2011 & 116 & 95.96 & 0.0078 & 3.44 & na & 0.24 & 0.005 & 0.21 & na & 0.030 & 0.0004 & $3.7 \mathrm{E}-05$ & $8.7 \mathrm{E}-6$ \\
\hline SE Field & 2009 & 123 & 90.07 & 0.0040 & 8.40 & na & 0.89 & 0.15 & 0.33 & na & 0.0076 & $1.3 \mathrm{E}-04$ & $9 \mathrm{E}-05$ & 0.0003 \\
\hline SE Field & 2010 & 135 & 81.22 & 0.00021 & 15.2 & na & 4.08 & 0.20 & 0.04 & na & 0.10 & 0.0017 & $1.8 \mathrm{E}-04$ & $2.4 \mathrm{E}-05$ \\
\hline SE Field & 2012 & 120 & 94.56 & 0.09 & 4.80 & na & 0.16 & 0.16 & 0.08 & na & 0.11 & 0.003 & $3.1 \mathrm{E}-04$ & $2.5 \mathrm{E}-05$ \\
\hline \multicolumn{15}{|c|}{ Menyailov et al., 1988} \\
\hline NE Field (4) & 1985 & 93 & 97.30 & 0.00091 & 2.35 & $5.2 \mathrm{E}-07$ & 0.25 & 0.065 & 0.0064 & $5.0 \mathrm{E}-05$ & 0.025 & 0.00013 & na & $3.9 \mathrm{E}-06$ \\
\hline Gremuchaya (18) & 1984 & 120 & 98.46 & 0.00012 & 1.28 & $5.0 \mathrm{E}-07$ & 0.17 & 0.059 & 0.0054 & $0.5 \mathrm{E}-05$ & 0.0081 & 0.00018 & na & $3.2 \mathrm{E}-06$ \\
\hline Florenskii (4) & $1979-83$ & 105 & 97.97 & $8.2 \mathrm{E}-05$ & 1.73 & $2.3 \mathrm{E}-07$ & 0.08 & 0.08 & 0.090 & $0.3 \mathrm{E}-05$ & 0.030 & na & na & $1.1 \mathrm{E}-04$ \\
\hline E Field (13) & $1979-85$ & 106 & 97.80 & $5.9 \mathrm{E}-05$ & 1.86 & $6.0 \mathrm{E}-06$ & 0.066 & 0.066 & 0.161 & $0.7 \mathrm{E}-05$ & 0.021 & 0.00026 & na & $7.2 \mathrm{E}-05$ \\
\hline SE Field (8) & $1979-84$ & 106 & 97.38 & 0.00165 & 1.96 & $1.8 \mathrm{E}-06$ & 0.19 & 0.15 & 0.192 & $1.6 \mathrm{E}-05$ & 0.043 & 0.00066 & na & $3.5 \mathrm{E}-05$ \\
\hline \multicolumn{15}{|c|}{ Bessonova et al., 2006} \\
\hline NE Field & 1998 & 130 & 95.50 & $1.2 \mathrm{E}-05$ & 3.64 & $5 E-06$ & 0.51 & 0.15 & 0.13 & 0.0005 & 0.023 & na & na & $2.4 \mathrm{E}-05$ \\
\hline \multicolumn{15}{|l|}{ This work } \\
\hline Well P2 & 1995 & 80 & $1.9^{\mathrm{a}}$ & 0.010 & 97.6 & na & - & - & - & - & 2.1 & 0.014 & 0.007 & 0.10 \\
\hline
\end{tabular}

a ) The gas content for Well P2 ( $\mathrm{mmol} / \mathrm{mol}$ ) was calculated using Ar concentration following the method described in Taran (2005).

In acidic solutions with low cation concentrations where $\left[\mathrm{Cl}_{\text {tot }}\right]$ is $\sim\left[\mathrm{Cl}^{-}\right]+[\mathrm{HCl}(\mathrm{aq})]$. In turn, concentration of $\mathrm{HCl}(\mathrm{aq})$ depends on $\left[\mathrm{Cl}^{-}\right]$ as

$\mathrm{m}_{\mathrm{HCl}(\mathrm{aq})}=\gamma \mathrm{K}_{\mathrm{d}}^{-1} 10^{-\mathrm{pH}} \mathrm{m}_{\mathrm{Cl}-}$

where $\mathrm{K}_{\mathrm{d}}$ is the dissociation constant for $\mathrm{HCl}$.

Then

$\mathrm{m}_{\mathrm{Cl}-}=\mathrm{m}_{\mathrm{Cltot}}\left(1+\gamma \mathrm{K}_{\mathrm{d}}^{-1} 10^{-\mathrm{pH}}\right)^{-1}$

and

$\mathrm{m}_{\mathrm{v}}=\mathrm{K}_{\mathrm{p}} \mathrm{K}_{\mathrm{d}} 10^{-\mathrm{pH}} \mathrm{m}_{\mathrm{Cltot}} \gamma\left(\mathrm{K}_{\mathrm{d}}+\gamma 10^{-\mathrm{pH}}\right)^{-1}$.

The dissociation constant for $\mathrm{HCl}$ under saturation pressure of water vapor varies from $10^{0.81}$ at $100{ }^{\circ} \mathrm{C}$ to $10^{-2.33}$ at $350{ }^{\circ} \mathrm{C}$ (Tagirov et al.,
1997). According to Simonson and Palmer (1993), the partitioning constant $\mathrm{K}_{\mathrm{p}}$ can be interpolated at $\leq 300{ }^{\circ} \mathrm{C}$ as:

$\log K_{p}=-3.34+0.0163 t$

where $\mathrm{t}$ in ${ }^{\circ} \mathrm{C}$. The activity coefficient for $\mathrm{Cl}^{-}$is estimated for a solution with $1 \mathrm{M}$ of the total chloride and $1 \mathrm{M}$ of the total sulfate at $\mathrm{pH}=0$, using a thermochemical computer code, The SOLVEQ code (Reed and Spycher, 1984) yields $\gamma$ values varying from 0.67 at $100^{\circ} \mathrm{C}$ to 0.29 at $300{ }^{\circ} \mathrm{C}$ using the extended Debye-Hückel equation. Using these data, a relationship between the concentration of $\mathrm{HCl}$ in steam vs temperature for the solution containing $1 \mathrm{M}$ of the total chloride and $1 \mathrm{M}$ of the total $\mathrm{SO}_{4}$ is illustrated at different $\mathrm{pH}$ in Fig. 4. The diagram shows that vapor separated from acidic chloride solution contains high $\mathrm{HCl}$ and the concentration of $\mathrm{HCl}$ becomes similar to that of high-temperature volcanic (magmatic) vapors (e.g., Taran and Zelenski, 2014). We believe that this is the case for Ebeko, as well as for the Poas low-temperature fumaroles (Rowe et al., 1992; Vaselli et al., 2003; Fischer et al., 2015). The presence

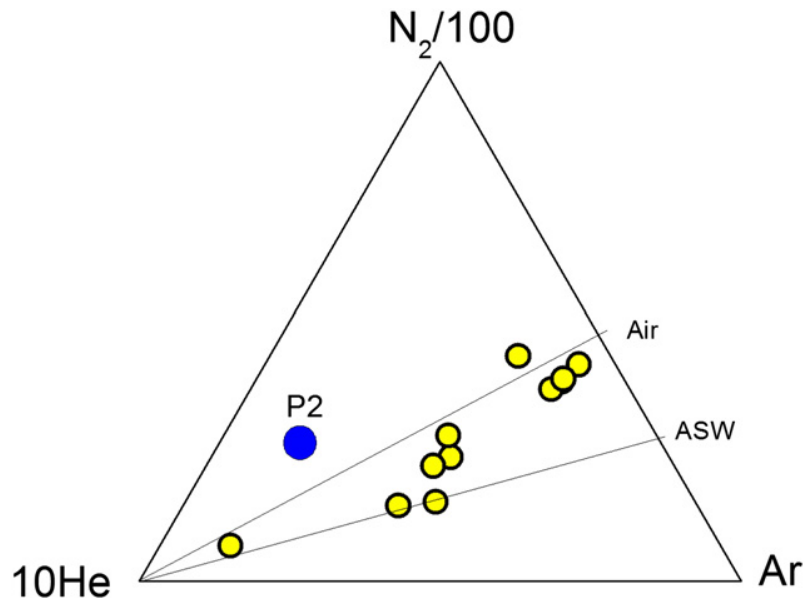

Fig. 2. The $\mathrm{N}_{2}-\mathrm{Ar}-\mathrm{He}$ ternary plot for fumarolic gases of Ebeko and gas from P2 well. ASW $=$ air-saturated water.

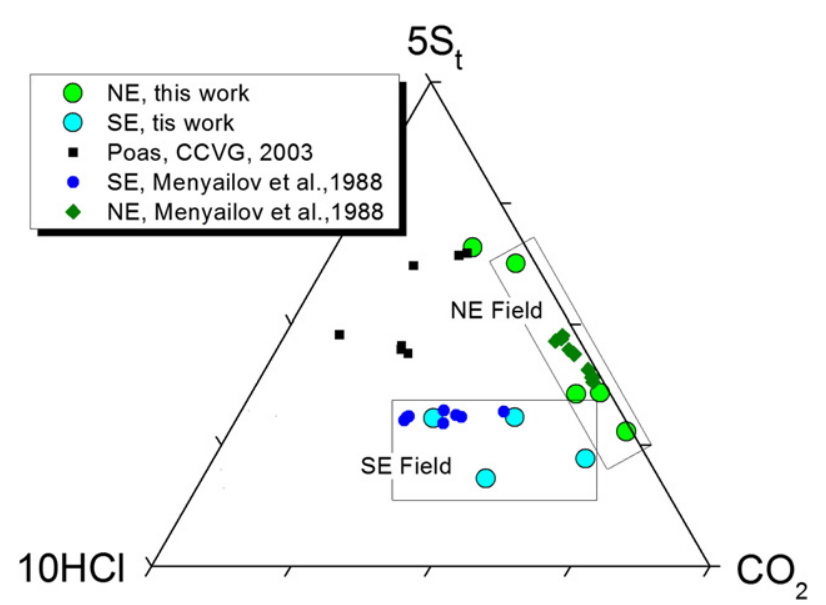

Fig. 3. Ternary diagram $\mathrm{CO}_{2}-\mathrm{S}_{\mathrm{t}}$ (total $\left.\mathrm{S}\right)-\mathrm{HCl}$ for fumarolic gases of Ebeko. For comparison, the compositions of low-temperature, $\mathrm{HCl}$-enriched gases of Poas volcano are also shown. 


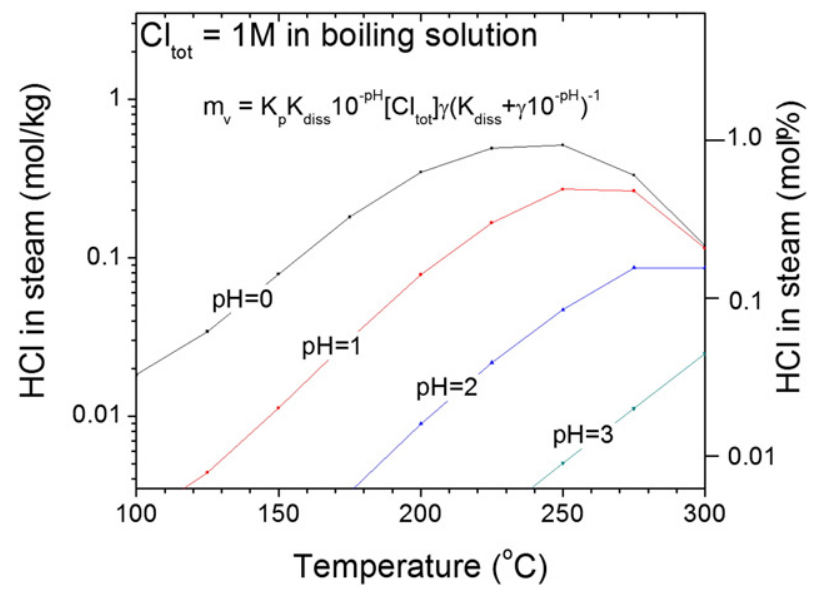

Fig. 4. Concentration of $\mathrm{HCl}$ in steam in equilibrium with boiling solution containing $1 \mathrm{M}$ of the total chloride and $1 \mathrm{M}$ of the total sulfate. See text for details.

of acidic brine beneath the Ebeko fumarolic fields is further supported by an unusual combination of $\mathrm{H}_{2} / \mathrm{H}_{2} \mathrm{O}$ and $\mathrm{CO} / \mathrm{CO}_{2}$ ratios in fumarolic gases (Fig. 5). The diagram shows the relationship between $\mathrm{R}_{\mathrm{CO}}$ and $\mathrm{R}_{\mathrm{H}}$ and between $\mathrm{R}_{\mathrm{CH} 4}$ and $\mathrm{R}_{\mathrm{H}}$, where $\mathrm{R}_{\mathrm{CO}}, \mathrm{R}_{\mathrm{CH} 4}$ and $\mathrm{R}_{\mathrm{H}}$ stand for log ( $\left.\mathrm{CO} / \mathrm{CO}_{2}\right), \log \left(\mathrm{CH}_{4} / \mathrm{CO}_{2}\right)$, and $\mathrm{R}_{\mathrm{H}}=\log \left(\mathrm{H}_{2} / \mathrm{H}_{2} \mathrm{O}\right)$, respectively. It also

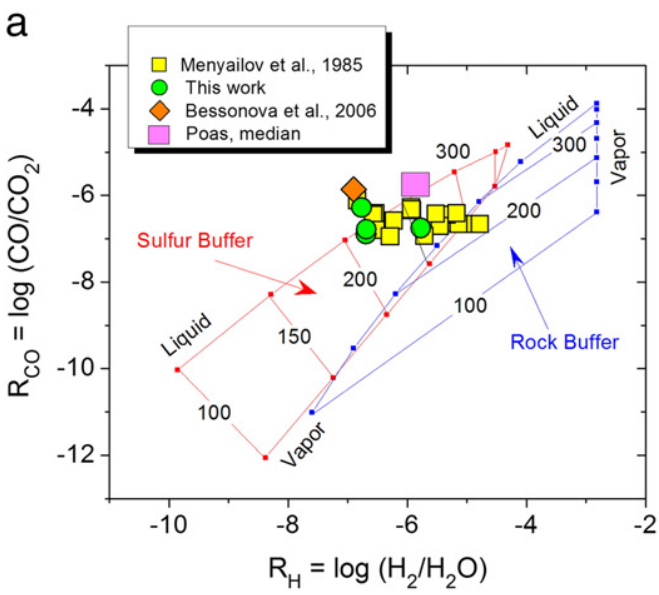

b

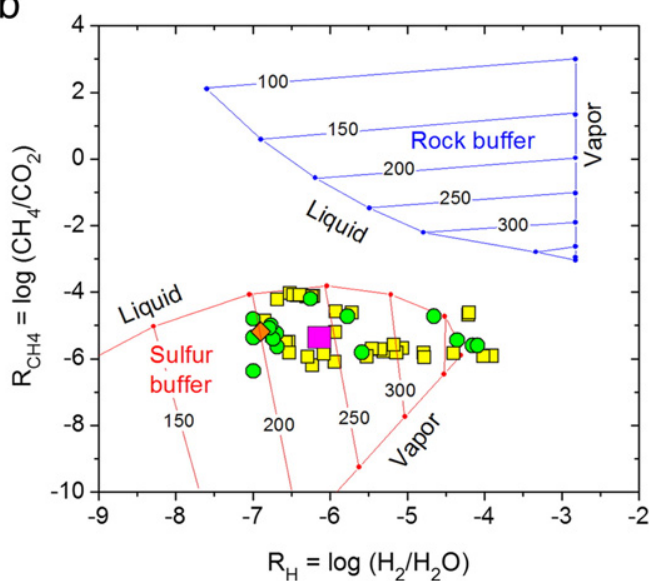

Fig. 5. Redox-diagrams for $\mathrm{H}$ - and $\mathrm{C}$-bearing gases at various temperatures in ${ }^{\circ} \mathrm{C}$. Data from Ebeko fumarolic fields plot within the two-phase area of sulfur buffer. A blue star is the composition of gas from the $\mathrm{P} 2$ well (only for $\mathrm{R}_{\mathrm{CH} 4}-\mathrm{R}_{\mathrm{H}}$ ). For comparison, it shows the composition of Poas fumaroles reported by Fischer et al. (2015). shows the compositions of gases in two buffer systems are plotted: for the so-called "rock buffer FeO-FeO 1.5 " (Giggenbach, 1987) and for "sulfur buffer" defined by Giggenbach (1987):

$\mathrm{SO}_{2}+3 \mathrm{H}_{2}=\mathrm{H}_{2} \mathrm{~S}+2 \mathrm{H}_{2} \mathrm{O}$

For the liquid phase the following equilibrium is chosen:

$\mathrm{H}_{2} \mathrm{SO}_{3}+3 \mathrm{H}_{2}(\mathrm{aq})=\mathrm{H}_{2} \mathrm{~S}(\mathrm{aq})+3 \mathrm{H}_{2} \mathrm{O}$

with the equilibrium constant $\log \mathrm{K}(8)=0.11+14,892 / \mathrm{T}$ (HSC-7, Roine, 2009). The diagram in Fig. 5 shows that almost all data are plotted within the two-phase region of the $\mathrm{S}$ redox-buffer, supporting the presence of acidic liquid beneath the fumarolic field of Ebeko. The majority of the data points are plotted between $200{ }^{\circ} \mathrm{C}$ and $300{ }^{\circ} \mathrm{C}$ on both diagrams despite a much slower kinetics of the reactions involving methane (e.g., Giggenbach, 1987).

\subsection{Geochemistry of waters}

The field data and locations of thermal springs and stream waters are shown in Table 2. The chemical compositions of waters from well P2, Ebeko thermal fields and Yurievskie springs (major components) are listed in Table 3. For the 2014 samples for the first time the oxygen and hydrogen isotopic composition of waters was analyzed.

\subsubsection{Isotopic composition of waters}

Isotopic compositions of Yurievskie springs plot close to the meteoric water line with a clear positive shifts in both $\delta^{18} \mathrm{O}$ and $\delta \mathrm{D}$ (Fig. 6a). These shifts are most likely due to mixing with magmatic vapor because there is a very good correlation between chloride concentration and both $\delta^{18} \mathrm{O}$ and $\delta \mathrm{D}$ (Fig. $6 \mathrm{~b}$ ). Note that Spring 1, the hottest springs among Yurievskie (sample Y8) is the most enriched in heavy isotopes. Interestingly, the isotopic composition of water from Well P2 is also plotted within the same trend, but with an additional ${ }^{18} \mathrm{O}$ shift due to water-rock interaction (Fig. 6a, b). The extrapolation of the trend observed in the water samples approaches the composition of "andesitic" (or arc-magmatic) water as it was defined by Taran et al. (1989) and Giggenbach (1992) (see also Taran and Zelenski (2014) for the Cl content in arc-volcanic fluids) (Fig. 6b).

Condensates of Ebeko fumaroles are significantly enriched in deuterium compared to the Yurievskie waters but almost all with negative values of $\delta^{18} \mathrm{O}$, indicating a large proportion of meteoric water in the acidic boiling brine beneath the fumarolic fields. The $\delta \mathrm{D}$ values for fumarolic vapors $(-40 \pm 10 \%$ ) are quite unusual considering the value of $-80 \%$ for local meteoric water. For many volcanoes in the world there is a good correlation between $\delta \mathrm{D}$ and vent temperature or $\mathrm{HCl}$ concentration in vapors (Taran and Zelenski, 2014). Low-temperature fumarolic vapor usually contains low $\mathrm{HCl}$ and $\delta \mathrm{D}$ close to the local meteoric water values (if there is no seawater contribution). Exceptions from this rule to the authors' knowledge are low temperature $\left(104{ }^{\circ} \mathrm{C}\right)$ fumaroles of Satsuma Iwojima (Shinohara et al., 1993), which formed from magmatic vapors through conductive cooling without contribution of meteoric water. The relationship between the isotopic composition of fumarolic vapors and chloride content in condensates and pools(Fig. 6b) does not clarify the situation. There is no correlation between $\mathrm{Cl}$ and $\delta \mathrm{D}$ because $\delta \mathrm{D}$ of condensates are all $\sim-40 \pm 10 \%$ independent on $\mathrm{Cl}$ contents. Similar $\delta \mathrm{D}$ values were reported by Menyailov et al. (1988) for Ebeko fumaroles sampled in 1979-1983 (Fig. 6a).The isotopic composition of water from drainless pools of Ebeko also does not show a correlation with the chloride concentrations (Table 3 , Fig. 6b) and widely varies at low $\mathrm{Cl}$ concentrations. The data may suggest that fumarolic vapors and pool waters undergo different degrees of equilibrium and/or kinetic isotopic fractionation associated with evaporation and different proportions of magmatic (volcanic) and meteoric waters. The composition of fumarolic condensates 
Table 3

Chemical (mg/L) and isotopic (\% VSMOW) composition of thermal and cold waters of Paramushir Island. na-not analyzed.

\begin{tabular}{|c|c|c|c|c|c|c|c|c|c|c|c|c|c|c|c|c|c|c|c|}
\hline Sample & date & $\mathrm{t}^{\circ} \mathrm{C}$ & $\mathrm{pH}_{\mathrm{lab}}$ & $\mathrm{Na}^{+}$ & $\mathrm{K}^{+}$ & $\mathrm{Ca}^{2+}$ & $\mathrm{Mg}^{2+}$ & $\mathrm{Al}^{3+}$ & $\mathrm{Fe}$ & $\mathrm{HCO}_{3}^{-}$ & $\mathrm{Cl}^{-}$ & $\mathrm{F}^{-}$ & $\mathrm{SO}_{4}^{2-}$ & B & $\mathrm{SiO}_{2}$ & $\delta \mathrm{D}$ & $\delta^{18} \mathrm{O}$ & $\mathrm{Sr}$ & ${ }^{87} \mathrm{Sr} /{ }^{86} \mathrm{Sr}$ \\
\hline \multicolumn{20}{|c|}{ Yurievskie springs } \\
\hline Y1 & 12.08 .2014 & 32 & 1.6 & 86 & 54 & 74 & 65 & 252 & 112 & 0 & 1118 & 1.9 & 2990 & na & 274 & -78.5 & -11.1 & 1.56 & 0.70317 \\
\hline Y2 & 12.08 .2014 & 17.6 & 3.2 & 44 & 22 & 97 & 33 & 73 & 4.5 & 0 & 211 & 0.1 & 614 & na & 241 & -81.9 & -12.0 & & \\
\hline Y3 & 12.08 .2014 & 18 & 2.0 & 53 & 37 & 91 & 41 & 162 & 59 & 0 & 628 & 1.7 & 1541 & na & 238 & -82.9 & -12.0 & 0.98 & 0.70316 \\
\hline Y4 & 12.08 .2014 & 7.2 & 3.3 & 9.4 & 3.8 & 13.3 & 7.2 & 16.7 & 0.5 & 0 & 36 & 1.3 & 134 & 1.1 & 84 & -84.0 & -12.3 & & \\
\hline Y5 & 12.08 .2014 & 9.1 & 3.1 & 11.8 & 5.4 & 14 & 9.4 & 22 & 4.7 & 0 & 36 & 0.6 & 221 & na & 87 & -83.3 & -12.2 & & \\
\hline Y6 & 12.08 .2014 & 5.3 & 7.2 & 4.8 & 1.4 & 4.9 & 1.4 & 0.0 & 0.1 & 8 & 5.7 & 0.3 & 19.3 & na & 56 & -84.5 & -12.4 & & \\
\hline Y7 & 12.08 .2014 & 20 & 1.8 & 51 & 37 & 87 & 39 & 146 & 66 & 0 & 632 & 2 & 1715 & 1.7 & 196 & -81.7 & -11.8 & & \\
\hline Y8 & 13.08 .2014 & 80.8 & 1.2 & 187 & 128 & 230 & 151 & 527 & 28 & 0 & 2734 & 15 & 6861 & 4.9 & 502 & -75.2 & -9.4 & 1.98 & 0.70315 \\
\hline Y10 & 13.08 .2014 & 60 & 1.4 & 139 & 94 & 139 & 109 & 356 & 181 & 0 & 1811 & 0.4 & 5176 & 2.5 & 376 & -77.2 & -10.6 & 2.17 & \\
\hline Y11 & 13.08 .2014 & 68.4 & 1.3 & 167 & 116 & 198 & 133 & 438 & 216 & 0 & 2325 & 13.3 & 6182 & 3.5 & 419 & -77.3 & -10.5 & 2.5 & 0.70316 \\
\hline Y12 & 13.08 .2014 & 34 & 1.8 & 86 & 66 & 7 & 57 & 257 & 98 & 0 & 799 & 1.7 & 2410 & na & 265 & -80.6 & -11.5 & 1.2 & 0.70315 \\
\hline Y13 & 13.08 .2014 & 6.7 & 3.5 & 4.3 & 1.4 & 7.6 & 2.4 & 0.9 & 0.0 & 0 & 7.1 & 0.4 & 39.1 & na & 49 & -81.1 & -12.0 & & \\
\hline Y14 & 13.08 .2014 & 45.1 & 1.5 & 111 & 80 & 133 & 85 & 311 & 160 & 0 & 1349 & 9.4 & 4053 & na & 334 & -78.5 & -10.8 & 1.7 & 0.70316 \\
\hline Y15 & 13.08 .2014 & 71.2 & 1.3 & 169 & 134 & 226 & 132 & 468 & 81 & 0 & 2308 & 13.6 & 6277 & 3.5 & 418 & -78.4 & -10.7 & 2.99 & 0.70316 \\
\hline Y16 & 13.08.2014 & 47.5 & 1.7 & 115 & 92 & 105 & 90 & 431 & 148 & 0 & 1367 & 0.4 & 3662 & 2.5 & 358 & -78.6 & -10.9 & & \\
\hline Y17 & 13.08 .2014 & 31.8 & 1.5 & 130 & 68 & 212 & 85 & 226 & 112 & 0 & 1312 & 2.2 & 3355 & 1.5 & 135 & -80.6 & -11.2 & & \\
\hline Y18 & 13.08 .2014 & 41.4 & 1.4 & 130 & 37 & 200 & 83 & 227 & 142 & 0 & 1383 & 2.4 & 3622 & 1.5 & 125 & -79.7 & -11.2 & & \\
\hline \multicolumn{20}{|c|}{ Ebeko volcano } \\
\hline E1 & 16.08 .2014 & & & & & & & & & & & & & & & & & 0.49 & 0.70319 \\
\hline E2 & 16.08 .2014 & 106 & 0.5 & 0.4 & 1.1 & & 0.1 & 738 & 2 & 0 & 25,276 & 0.2 & 94 & na & 0.3 & -35.9 & -3.5 & 0.05 & 0.70426 \\
\hline E4 & 16.08 .2014 & 82 & 0.8 & 9.2 & 9.7 & 0.4 & 1.3 & 63 & 12.3 & 0 & 5148 & $<0.2$ & 4450 & na & 227 & -28.7 & -0.6 & 0.27 & 0.70320 \\
\hline E5 & 16.08 .2014 & 105 & 0.6 & 3.8 & 3.3 & 1.5 & 4.5 & 25 & 4.3 & 0 & 16,152 & 22 & 688 & na & 3.9 & -28.7 & -0.6 & 0.06 & \\
\hline E6 & 20.08 .2014 & 13.4 & 2.4 & 8.1 & 2.6 & 58.7 & 7.3 & 23 & 6.2 & 0 & 25.6 & 0.7 & 345 & na & 74 & -43.5 & -4.2 & & \\
\hline E7 & 20.08 .2014 & 72.5 & 1.1 & 28 & 47 & 0.6 & 3.5 & 231 & 32 & 0 & 192 & $<0.2$ & 8566 & na & 256 & -22.0 & 3.6 & 1.74 & \\
\hline E8 & 20.08 .2014 & 80 & 1.5 & 13 & 17 & 0.5 & 3.6 & 110 & 17.2 & 0 & 11 & $<0.2$ & 3270 & na & 304 & -45.5 & -1.5 & & \\
\hline E9 & 20.08 .2014 & 109 & 1.7 & 0.3 & 0.6 & 0.1 & 0.05 & 2.9 & 0.6 & 0 & 909 & $<0.2$ & 14 & na & 3.4 & -47.0 & -4.8 & & \\
\hline E10 & 20.08 .2014 & 16 & 2.3 & 2.5 & 1.8 & 66 & 1.2 & 12.2 & 7.9 & 0 & 106 & 0.7 & 291 & na & 20 & -78.6 & -10.8 & & \\
\hline \multicolumn{20}{|l|}{ Well P2 } \\
\hline P2 & 10.08 .2014 & 70.9 & 7.9 & 2516 & 152 & 23 & 16 & 10.3 & 0.1 & 1928 & 2716 & 0.6 & 192 & 5.4 & 125 & -73.7 & -7.6 & 2.05 & \\
\hline
\end{tabular}

derived from the boiling of concentrated acidic brine (see discussion above) may also indicate that the original brine is isotopically lighter in $\delta \mathrm{D}$ and heavier in $\delta^{18} \mathrm{O}$. This suggestion is based on the experimental studies of the isotopic fractionation of water between vapor and concentrated $\mathrm{NaCl}$ and $\mathrm{KCl}$ brines (Schmulovich et al., 1999; Driesner and Seward, 2000). Water vapor has lower deuterium than liquid water at low temperatures, but vapor is enriched in deuterium compared to liquid water above $\sim 220^{\circ} \mathrm{C}$ with a maximum fractionation of $\sim 5 \%$ at $\sim 280^{\circ} \mathrm{C}$ (Horita and Wesolowski, 1994). Concentrated aqueous solutions (2-4 M) display this inversion temperature for isotopic fractionation at lower temperatures, $<200{ }^{\circ} \mathrm{C}$, and vapor is enriched in deuterium relatively brine by $~ 10 \%$ at $>250{ }^{\circ} \mathrm{C}$ (Driesner and Seward, 2000). Therefore, it is conceivable that the acidic boiling brine beneath the fumarolic fields of Ebeko has low $\delta \mathrm{D}$ values in a range of $-50 \pm 5 \%$ if the temperature is greater than $250{ }^{\circ} \mathrm{C}$. The positive shift in ${ }^{18} \mathrm{O}$ for the concentrated $\mathrm{NaCl}$ solutions is near $1 \%$ at $>250 \mathrm{C}$. The estimated isotopic composition of the Ebeko brine therefore can be near $\delta \mathrm{D}=-50 \%$ and $\delta^{18} \mathrm{O}=-3 \%$, which is close to the mixing line between local meteoric water of Ebeko and the postulated arc-magmatic water (Fig. 6a).

\subsubsection{Water chemistry: major components}

All waters from the Yurievskie springs and Ebeko pools are ultraacidic, with $\mathrm{pH}<2$. The Yurievskie waters are of the $\mathrm{SO}_{4}-\mathrm{Cl}$ type (by weight), whereas the $\mathrm{SO}_{4} / \mathrm{Cl}$ ratio in Ebeko pools show low $(<1)$ and varying $\mathrm{SO}_{4} / \mathrm{Cl}$ ratios (Table 3, Fig. 7c). The data plotted in Fig. 7a-c are from this work (2005 and after) and are taken from Zelenov (1972), Nikitina (1978) and Fazlullin (1999). Similar $\mathrm{SO}_{4} / \mathrm{Cl}$ ratios in Yurievskie springs ( 1:1 molar and 3:1 by weight, Fig. 7c) indicate a simple mixing between meteoric water and one endmember component with high $\mathrm{Cl}$ and $\mathrm{SO}_{4}$. The mixing likely occurs at shallow levels based on the chloride vs temperature plot of all available data (Fig. 8). Spring 1 has been the most concentrated and hottest since the first sampling in 1955 (Zelenov, 1972), but both salinity and temperature gradually decreased from almost boiling $\left(95^{\circ} \mathrm{C}\right)$ with $\mathrm{Cl}$ content $>5000 \mathrm{mg} / \mathrm{L}$ in 1954 to $78{ }^{\circ} \mathrm{C}$ and $\sim 2500 \mathrm{mg} / \mathrm{L}$ of $\mathrm{Cl}$ in 2014 (Fig. 7a). The concentrations of chloride and sulfate in the Yurievskie springs are decreasing over time with a constant $\mathrm{SO}_{4} / \mathrm{Cl}$ ratio (note that the " $\mathrm{Cl}$ vs Date" diagram is a semi-log plot). The chemical composition of the Ebeko pools is highly variable both in salinities and $\mathrm{SO}_{4} / \mathrm{Cl}$. Chloride concentrations in pools from the South (E1, E2) and SE fields (E3-E5) of Ebeko are always significantly higher (E3 sample, Table 3) than those in the NE field (E7-E9, Table 3 ). This is in accordance with the low $\mathrm{HCl}$ contents in the NE fumaroles compared to fumaroles of the SE field (Table 1). A ternary plot for cations in waters of the Ebeko pools and Yurievskie springs (Fig. 9) demonstrates notable difference between these two thermal manifestations. Waters from Yurievskie springs are similar in $(\mathrm{Na}+\mathrm{K}) / \mathrm{Mg}$ ratio and vary in Ca. This varying content of Ca is likely due to the precipitation and dissolution of anhydrite. Waters from Ebeko pools are plotted close to the main trend but compositions significantly scatter around this trend. Such a composition of cations is common for waters from ultra-acidic lakes in craters of andesitic volcanoes where strong acidity of water is capable to leach bulk of cations. Indeed, the average composition of the unaltered Ebeko andesitic rock (Martynov et al., 2010) plots within the area of water compositions. Such a compositionof cations is common for waters from ultra-acidic lakes in craters of andesitic volcanoes. An inserted ternary plot in Fig. 9 compares the data points for Poas, Ruapehu and Copahue crater lakes (Rowe et al., 1992; Christenson and Wood, 1993; Varekamp et al., 2001) with the data for the Ebeko + Yurieva composition.

It has been suggested that an increase in $\mathrm{Mg}$ in acidic waters precedes volcanic eruptions as it was first shown by Giggenbach (1974) for Ruapehu crater lake and this phenomenon was repeated later at Ruapehu and Copahue volcanoes (Christenson and Wood, 1993; Varekamp et al., 2001). Giggenbach (1974) suggested that this is a response on the intrusion of new magma into the acidic aquifer. All available data from the Yurievskie springs since 1955 are plotted in 
a

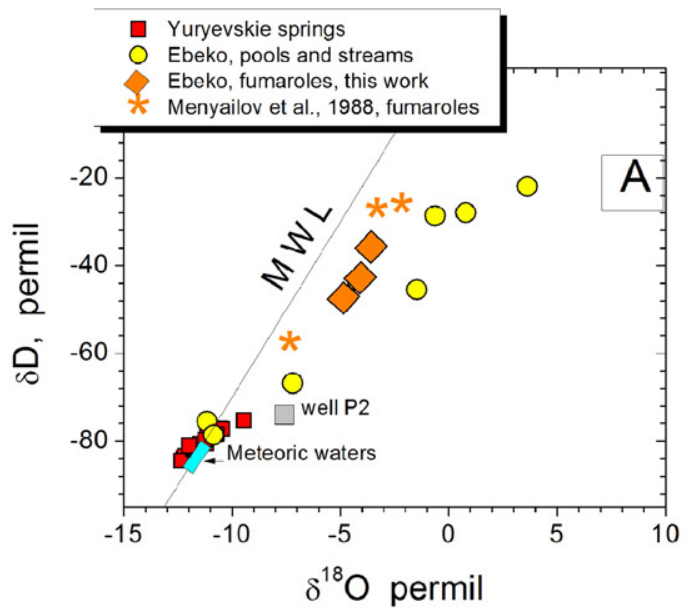

b
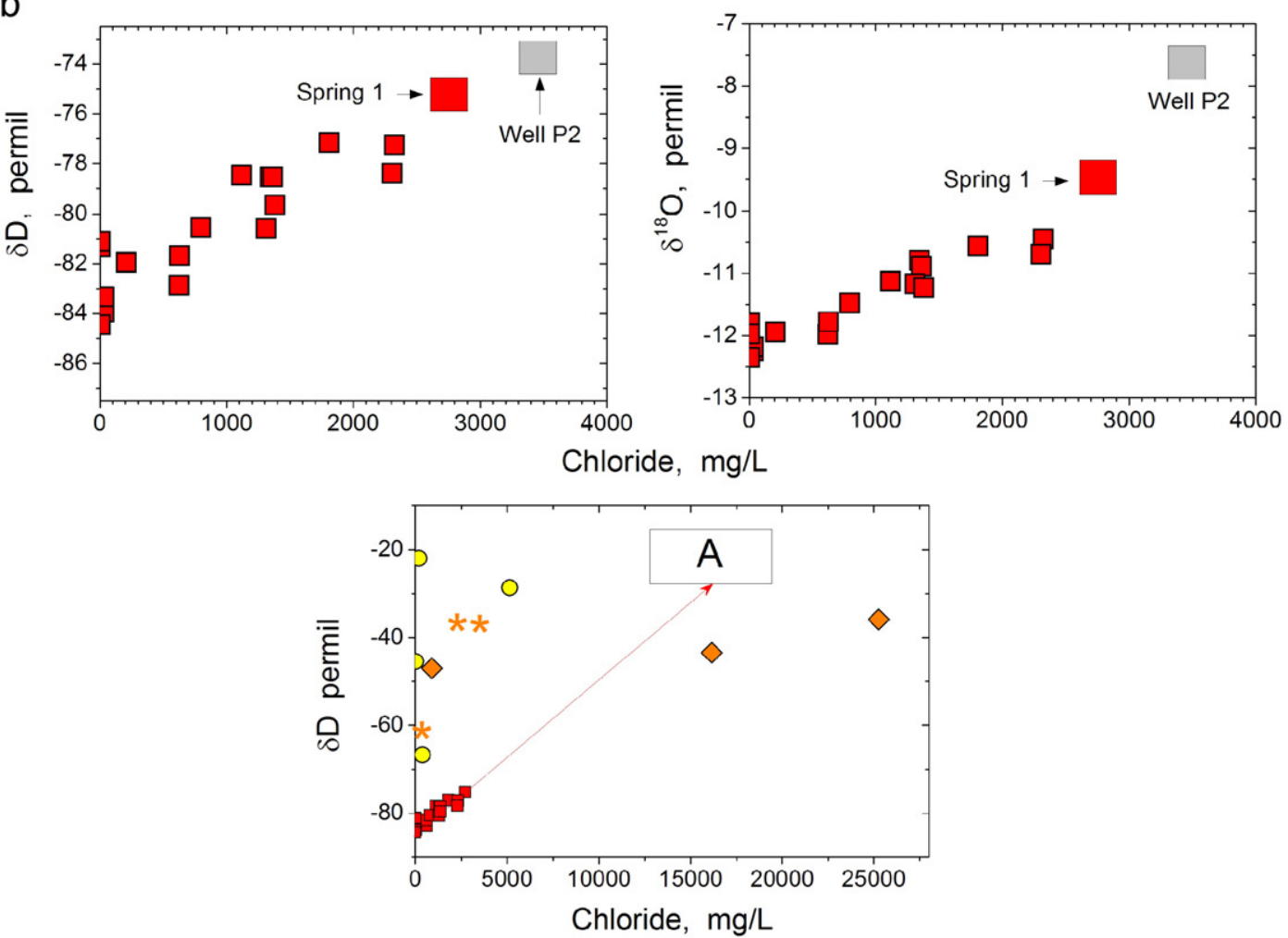

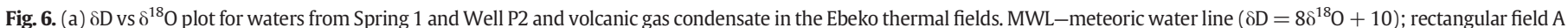

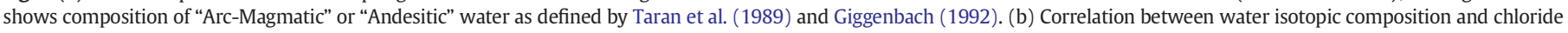
content for waters from Yurievskie springs and Ebeko pools. Rectangular field A shows the compositions of arc-magmatic gases (Taran and Zelenski, 2014).

Fig. 10(a, b), where each data set contains from 5 to 30 analyses. A positive correlation is observed between $\mathrm{Mg}$ and $\mathrm{Cl}$ in Fig. 10a with a mean $\mathrm{Mg} / \mathrm{Cl}$ of 0.059 and a standard deviation for the slope of 0.014 . The only statistically significant increase of the relative $\mathrm{Mg}$ concentration occurred in 2010 during the 2005-2011 cycle of eruptions and enhanced fumarolic activity of Ebeko (Fig. 10a, b).The data confirms that the acidic aquifer feeding Yurievskie springs and fumarolic fields of Ebeko may represent a common volcano-hydrothermal system, and therefore, the chemical monitoring of Yurievskie springs may be an effective geochemical tool for predicting eruptive activity of Ebeko volcano.

\subsubsection{Water chemistry: trace elements, REE and ${ }^{87} \mathrm{Sr} /{ }^{86} \mathrm{Sr}$}

More than 40 trace elements and a full set of REE were analyzed in waters of the Yurievskie springs and pools from fumarolic fields of
Ebeko (Table 4). Enrichment factor of element i, $\mathrm{F}_{\mathrm{i}}$, were obtained by normalizing the concentration of element, $E_{i}$, to $M g, F_{i}=\left(E_{i} / M g\right)_{w} /$ $\left(E_{\mathrm{i}} / \mathrm{Mg}\right)_{\mathrm{r}}$, where subscripts $\mathrm{w}$ and $\mathrm{r}$ correspond to water and rock, respectively, the ultra-acidic waters of Yurievskie springs show a pattern similar to other volcano-hydrothermal systems and crater lakes, such as Keli Mutu and Kawa Ijen crater lakes in Indonesia (Pasternack and Varekamp, 1994; Delmelle et al., 2000), El Chichon acid springs in Mexico (Taran et al., 2008; Peiffer et al., 2011) and Shiashkotan volcanic field, Russia (Kalacheva et al., 2015). The composition of rocks is a mean value of andesitic rocks of Paramushir Island (Avdeiko et al, 1992; Martynov et al., 2010). Several elements are not available in the data set of Paramushir andesites and for them it was used the mean value of arc andesite from Kelemen et al. (2007). Elements showing $F_{i} \sim 1$ are those completely dissolved from host rocks and they include rare earth elements (REE). Elements that have high $\mathrm{F}_{\mathrm{i}},>1$ include $\mathrm{B}, \mathrm{Br}, \mathrm{I}$, 


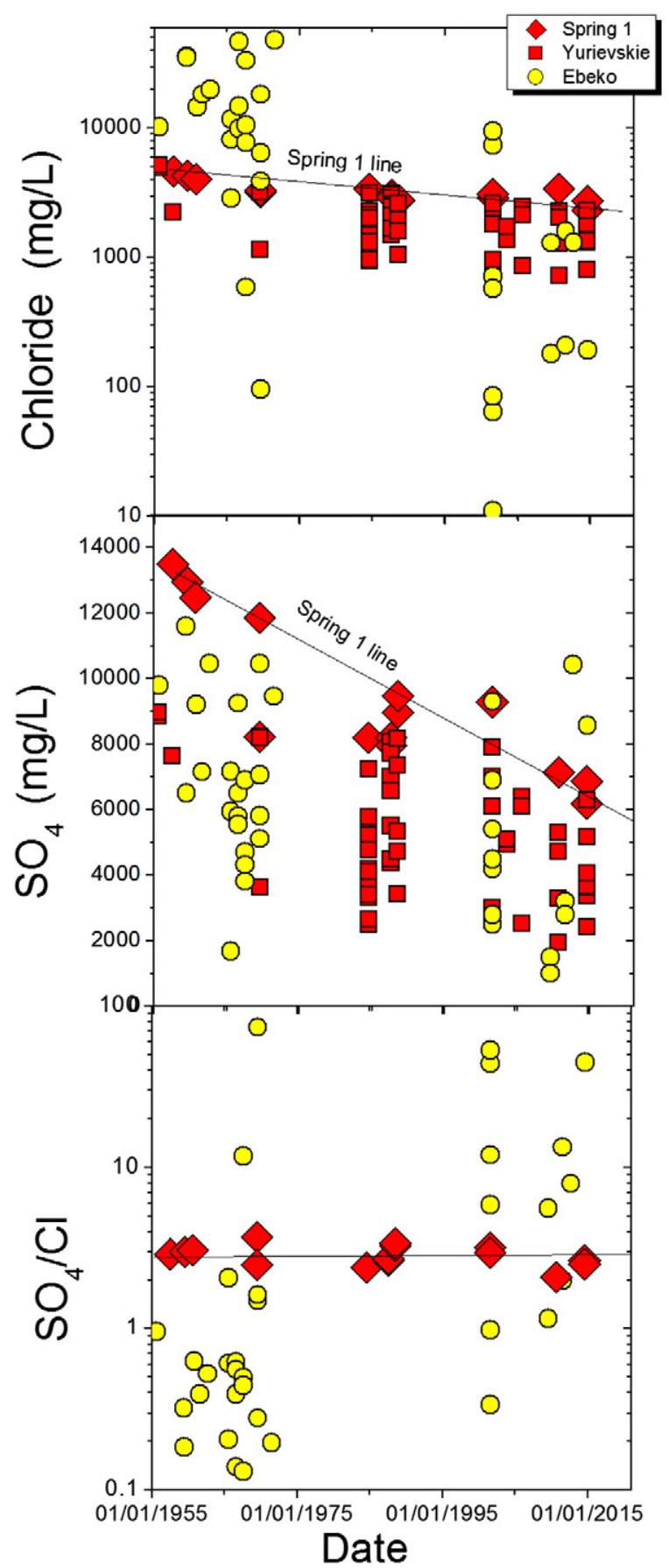

Fig. 7. Chloride, sulfate and $\mathrm{SO}_{4} / \mathrm{Cl}$ in thermal waters of Yurievskie and Ebeko over time during the entire period of observation from 1955 to 2015. See text for details and sources of the data.

As, $\mathrm{Se}, \mathrm{Sb}, \mathrm{Cs}, \mathrm{Rb}$. They are fluid-mobile elements and may originate from external sources, such as magmatic vapors or sedimentary rocks. The third group of elements are those with $\mathrm{F}_{\mathrm{i}}<1$. They may have been lost as precipitates and co-precipitate as sulfides ( $\mathrm{Mo}, \mathrm{Cu}, \mathrm{Ni}, \mathrm{Co}$ ), sulfates $(\mathrm{Ba}, \mathrm{Sr}$ ) or adsorbed on secondary phases. For example, highly charged cations, such as $\mathrm{Sb}, \mathrm{Zr}$, and $\mathrm{Nb}$ are easily adsorbed on the surface of secondary minerals. Data points for the Ebeko pools, though generally follow the Yurievskie trend, scatter significantly and on average are plotted higher than the Yurievskie points (Fig. 11).

The REE patterns normalized to chondrite for the Ebeko andesites (Martynov et al., 2010) and acidic waters of Yurieva springs and

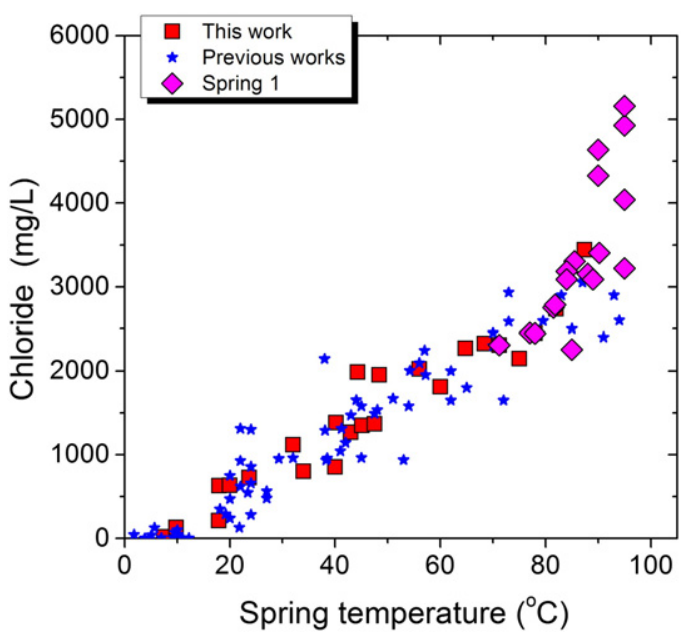

Fig. 8. Chloride vs temperature for Yurievskie spring waters. Data for Spring 1 are from this work (2003-2014) and previous works (see text).

Ebeko pools are shown in Fig. 12. Rocks show a pattern common in arc andesite, high LREE without low Eu. The REE for waters normalized to rock (average of 3 samples, Martynov et al., 2010) is essentially flat indicating a congruent dissolution of REE from the rock matrix in the ultra-acidic water. Waters from the two thermal fields (Yurieva and Ebeko) generally cannot be distinguished using these plots except of one 2005 sample (Fig. 12) from a pool at Ebeko with a pattern similar to that for some other acidic water (e.g., Tamagawa springs, Japan, Sanada et al., 2006). The difference between the total REE concentrations in waters can be related to the differences in the $\mathrm{Al}+\mathrm{Fe}$ content for spring waters and differences in $\mathrm{pH}$. Positive correlation between total REE concentration and $\mathrm{Al}+\mathrm{Fe}$ has been shown by Kikawada et al. (1993) in acid waters of the Kusatsu-Shirane area in Japan. Data for Yurievskie and Ebeko waters fall near the same trend on the loglog plot of the total REE vs molar Fe + Al concentration (Fig. 13) as the acid crater lake waters in Japan and acidic waters from Shiashkotan volcanic island (Kalacheva et al., 2015). The evidence suggests that the $\mathrm{Al}+\mathrm{Fe}$ concentration is a good proxy for the total REE concentration in very acidic thermal waters.

Isotopic composition of dissolved $\mathrm{Sr}$ dissolved in thermal waters is a good tracer of the origin of the aquifer rocks. For example, Peiffer et al. (2011) used ${ }^{87} \mathrm{Sr} /{ }^{86} \mathrm{Sr}$ and $\mathrm{Ca} / \mathrm{Sr}$ ratios of El Chichon volcano-hydrothermal system to distinguish two main aquifers; one composed of volcanic rocks and another deeper one representing sedimentary rocks. In our study, both Yurievskie spring waters and Ebeko pool waters show

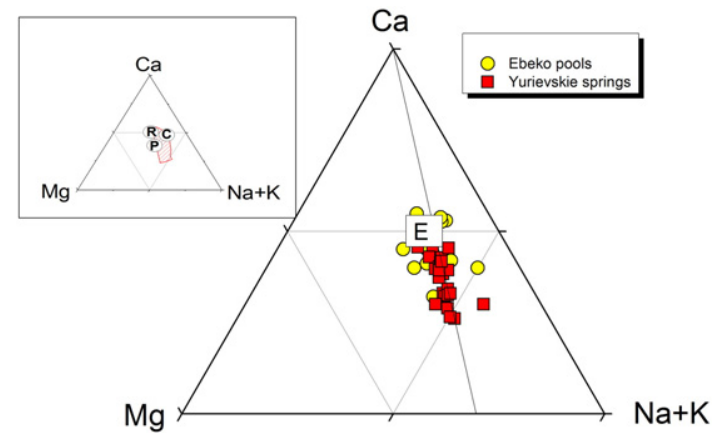

Fig. 9. Relative concentrations of $\mathrm{Na}+\mathrm{K}, \mathrm{Ca}$ and $\mathrm{Mg}$ in waters from Yurievskie springs and Ebeko pools with a square E corresponding to average composition of Ebeko andesites (Martynov et al., 2010). Inserted a diagram showing average composition of Ruapehu (R), Poas (P) and Copahue (C) crater lakes (see text for details). 

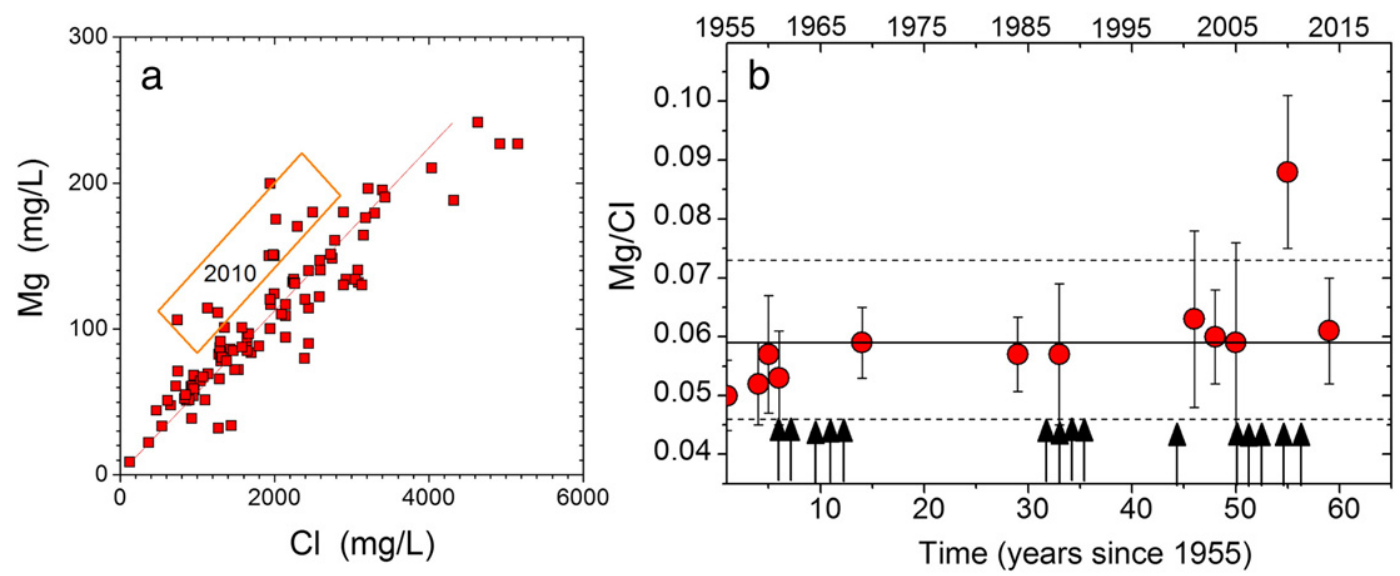

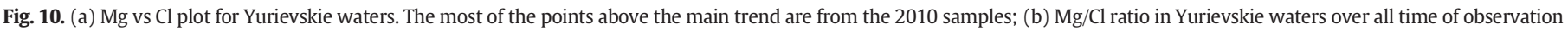

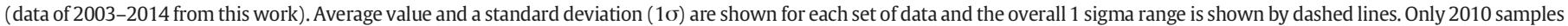
are statistically above the mean value. Black arrows approximately mark periods of phreatic events.

very similar ${ }^{87} \mathrm{Sr} /{ }^{86} \mathrm{Sr}$ values of $\sim 0.7032$ (Table 3), very similar to the $\mathrm{Sr}$ isotopic composition of andesites of Ebeko (Martynov et al., 2010). One value of 0.70426 is obtained for a $\mathrm{Cl}$-rich condensate of a fumarole with a low $\mathrm{Sr}$ concentration of $0.05 \mathrm{ppm}$. A slightly high value may suggest a contribution of sea spray since the site is close to the ocean and sea water contains $\mathrm{Sr}$ with high ${ }^{87} \mathrm{Sr} /{ }^{86} \mathrm{Sr}, 0.7092$.

Table 4

Trace element abundances $(\mu \mathrm{g} / \mathrm{L})$ in thermal waters of Paramushir island.

REE are highlighted by bold italic font, $<\mathrm{dl}-$ below detection limit.

\begin{tabular}{|c|c|c|c|c|c|c|c|c|c|c|c|c|c|c|}
\hline Element & $\mathrm{Y} 1$ & Y3 & Y10 & Y11 & Y12 & Y14 & Y15 & E1 & E2 & E3 & E4 & E5 & E7 & P2 \\
\hline $\mathrm{pH}$ & 1.6 & 2.0 & 1.4 & 1.3 & 1.8 & 1.5 & 1.3 & & 0.50 & 0.3 & 0.8 & 0.6 & 1.1 & 7.9 \\
\hline $\mathrm{Cl} \mathrm{mg/L}$ & 1118 & 628 & 1811 & 2325 & 799 & 1349 & 2308 & & 25,276 & nd & 5148 & 16,152 & 192 & 2716 \\
\hline $\mathrm{Li}$ & 48 & 26 & 45 & 48 & 34 & 33 & 67 & 8.8 & $<\mathrm{dl}$ & 28 & $<\mathrm{dl}$ & $<\mathrm{dl}$ & $<\mathrm{dl}$ & 624 \\
\hline $\mathrm{Be}$ & 4.2 & 3.9 & 1.5 & 1.5 & 3.7 & 4.1 & 2.1 & 3.3 & $<\mathrm{dl}$ & 0.91 & $<\mathrm{dl}$ & $<\mathrm{dl}$ & $<\mathrm{dl}$ & 2.9 \\
\hline Sc & 87 & 72 & 103 & 112 & 66 & 86 & 144 & 125 & $<\mathrm{dl}$ & 116 & $<\mathrm{dl}$ & $<\mathrm{dl}$ & $<\mathrm{dl}$ & 33 \\
\hline $\mathrm{Ti}$ & 50 & 29 & 68 & 78 & 38 & 58 & 92 & 28 & 1384 & 3702 & 166 & 1634 & 12 & \\
\hline V & 542 & 282 & 688 & 52 & 422 & 603 & 966 & 158 & 24 & 1311 & 92 & 22 & 493 & 1.7 \\
\hline $\mathrm{Cr}$ & 101 & 58 & 135 & 156 & 75 & 115 & 184 & 11.4 & 692 & 1851 & 83 & 817 & 6.1 & 104 \\
\hline $\mathrm{Mn}$ & 5981 & 4058 & 8922 & 10,290 & 4400 & 7012 & 11,532 & 930.5 & 2470 & 9023 & 253 & 283 & 649 & 99 \\
\hline Co & 7.9 & 9.3 & 7.8 & 17.0 & 3.8 & 27 & 10.5 & 2.0 & $<\mathrm{dl}$ & 119 & 25 & 1.4 & 19.3 & 0.5 \\
\hline $\mathrm{Ni}$ & 24 & 17.4 & 32 & 39 & 13.7 & 34 & 40 & 8.0 & $<\mathrm{dl}$ & 45 & $<\mathrm{dl}$ & 369 & $<\mathrm{dl}$ & 2.2 \\
\hline $\mathrm{Cu}$ & 18.0 & 23 & $<\mathrm{dl}$ & 15.6 & 9.8 & 60 & 4.9 & 13.9 & $<\mathrm{dl}$ & 499 & $<\mathrm{dl}$ & $<\mathrm{dl}$ & $<\mathrm{dl}$ & 73 \\
\hline $\mathrm{Zn}$ & 588 & 380 & 866 & 994 & 399 & 686 & 1123 & 69 & 1398 & 1188 & $<\mathrm{dl}$ & 101 & 11.3 & 1.6 \\
\hline As & 555 & 162 & 1063 & 1212 & 309 & 623 & 1325 & 201 & 132 & 2792 & 89 & 2171 & 114 & 530 \\
\hline $\mathrm{Se}$ & 11.6 & 8.4 & 21 & 25 & 7.5 & 16.9 & 29 & $<\mathrm{dl}$ & 13 & $<\mathrm{dl}$ & $<\mathrm{dl}$ & 281 & $<\mathrm{dl}$ & 50 \\
\hline $\mathrm{Rb}$ & 168 & 108 & 275 & 320 & 129 & 203 & 350 & $<\mathrm{dl}$ & 3.9 & 194 & 35 & 5.4 & 41 & 49 \\
\hline Y & 33 & 24 & 51 & 59 & 23 & 40 & 65 & $<\mathrm{dl}$ & 0.04 & 128 & 8.6 & 2.2 & 14.2 & 0.17 \\
\hline $\mathrm{Zr}$ & 0.29 & $<\mathrm{dl}$ & 8.3 & 8.0 & $<\mathrm{dl}$ & 0.46 & 7.1 & 2.1 & 14.1 & 146 & 56 & 44 & 54 & $<\mathrm{dl}$ \\
\hline Mo & $<\mathrm{dl}$ & $<\mathrm{dl}$ & 0.04 & 1.1 & $<\mathrm{dl}$ & $<\mathrm{dl}$ & 0.24 & $<\mathrm{dl}$ & $<\mathrm{dl}$ & 13.5 & $<\mathrm{dl}$ & $<\mathrm{dl}$ & $<\mathrm{dl}$ & $<\mathrm{dl}$ \\
\hline $\mathrm{Ag}$ & $<\mathrm{dl}$ & $<\mathrm{dl}$ & $<\mathrm{dl}$ & $<\mathrm{dl}$ & $<\mathrm{dl}$ & $<\mathrm{dl}$ & 0.26 & $<\mathrm{dl}$ & $<\mathrm{dl}$ & 7.7 & $<\mathrm{dl}$ & $<\mathrm{dl}$ & $<\mathrm{dl}$ & $<\mathrm{dl}$ \\
\hline $\mathrm{Cd}$ & 5.0 & 2.8 & 8.7 & 9.6 & 2.5 & 6.7 & 9.6 & 3.5 & 0.95 & 32.9 & $<\mathrm{dl}$ & 0.13 & 2.4 & 21.6 \\
\hline Sn & 3.5 & 3.3 & 0.04 & $<\mathrm{dl}$ & 2.6 & 2.4 & 0.17 & 2.8 & 8.8 & 108 & $<\mathrm{dl}$ & 10.9 & $<\mathrm{dl}$ & 3.1 \\
\hline $\mathrm{Sb}$ & 4.3 & 3.8 & 1.7 & 0.85 & 3.6 & 3.4 & 2.6 & 3.3 & $<\mathrm{dl}$ & 70 & $<\mathrm{dl}$ & 35 & $<\mathrm{dl}$ & 4.9 \\
\hline Cs & 14.6 & 9.0 & 27 & 32 & 10.9 & 18.9 & 33 & 3.2 & $<\mathrm{dl}$ & 3.8 & $<\mathrm{dl}$ & $<\mathrm{dl}$ & $<\mathrm{dl}$ & 44 \\
\hline $\mathrm{Ba}$ & 75 & 44 & 132 & 119 & 36 & 49 & 129 & 67 & 36 & 1133 & 76 & 1037 & 89 & 1140 \\
\hline La & 30 & 20.0 & 49 & 60 & 23 & 38 & 66 & 13.0 & $<\boldsymbol{d l}$ & 90 & 6.0 & 0.44 & 33 & 0.09 \\
\hline $\mathrm{Ce}$ & 73 & 50 & 122 & 148 & 58 & 94 & 166 & 31 & 1.9 & 190 & 17.8 & 2.3 & 71 & 0.11 \\
\hline $\mathrm{Pr}$ & 9.4 & 6.8 & 15.5 & 18.9 & 7.5 & 12.2 & 21 & 4.1 & $<\boldsymbol{d l}$ & 22 & 0.99 & $<\boldsymbol{d l}$ & 6.4 & 0.05 \\
\hline$N d$ & 41 & 29 & 68 & 82 & 32 & 52 & 89 & 17.5 & 0.36 & 102 & 9.7 & 0.53 & 28 & 0.14 \\
\hline$S m$ & 8.9 & 6.5 & 14.9 & 18.3 & 6.8 & 11.4 & 19.4 & 4.1 & $<\mathrm{dl}$ & 22.6 & 0.42 & $<\mathrm{dl}$ & 3.1 & 0.08 \\
\hline $\boldsymbol{E u}$ & 2.7 & 2.1 & 4.5 & 5.5 & 2.0 & 3.5 & 5.9 & 1.4 & $<\mathrm{dl}$ & 6.8 & $<\boldsymbol{d l}$ & $<\mathrm{dl}$ & $<\boldsymbol{d l}$ & 0.35 \\
\hline Gd & 8.5 & 6.3 & 14.4 & 17.6 & 6.3 & 11.0 & 18.6 & 4.0 & $<\mathrm{dl}$ & 25 & 0.66 & $<\mathrm{dl}$ & 3.6 & 0.03 \\
\hline$T b$ & 1.3 & 1.04 & 2.0 & 2.5 & 0.92 & 1.7 & 2.6 & 0.68 & $<\mathrm{dl}$ & 2.8 & dl & $<\mathrm{dl}$ & dl & 0.03 \\
\hline Dy & 6.7 & 5.1 & 11.8 & 14.4 & 4.7 & 8.8 & 15 & 3.9 & $<\mathrm{dl}$ & 24 & 0.37 & $<\mathrm{dl}$ & 1.9 & 0.02 \\
\hline Ho & 1.4 & 1.1 & 2.2 & 2.8 & 0.98 & 1.8 & 2.9 & 0.84 & $<\mathrm{dl}$ & 4.0 & $<\mathrm{dl}$ & $<\mathrm{dl}$ & dl & 0.04 \\
\hline Er & 4.2 & 3.1 & 7.3 & 8.8 & 2.9 & 5.5 & 9.1 & 2.5 & $<\mathrm{dl}$ & 15.9 & $<\mathrm{dl}$ & $<\mathrm{dl}$ & 0.82 & 0.04 \\
\hline$T m$ & 0.62 & 0.58 & 0.91 & 1.1 & 0.45 & 0.81 & 1.2 & 0.41 & $<\mathrm{dl}$ & 1.04 & $<\mathrm{dl}$ & $<\mathrm{dl}$ & dl & 0.04 \\
\hline$Y b$ & 4.0 & 3.0 & 7.3 & 9.0 & 2.8 & 5.2 & 9.1 & 2.5 & $<\mathrm{dl}$ & 16.7 & 0.08 & $<\mathrm{dl}$ & 0.87 & 0.01 \\
\hline$L u$ & 0.64 & 0.57 & 0.9 & 1.2 & 0.45 & 0.83 & 1.2 & 0.41 & $<\mathrm{dl}$ & 1.3 & $<\mathrm{dl}$ & $<\mathrm{dl}$ & $<\mathrm{dl}$ & 0.03 \\
\hline $\mathrm{Hf}$ & 0.09 & 0.07 & $<\mathrm{dl}$ & $<\mathrm{dl}$ & 0.07 & 0.1 & $<\mathrm{dl}$ & 0.18 & $<\mathrm{dl}$ & 2.5 & $<\mathrm{dl}$ & $<\mathrm{dl}$ & $<\mathrm{dl}$ & 0.05 \\
\hline Та & 0.33 & 0.36 & $<\mathrm{dl}$ & $<\mathrm{dl}$ & 0.33 & 0.33 & $<\mathrm{dl}$ & 0.33 & $<\mathrm{dl}$ & $<\mathrm{dl}$ & $<\mathrm{dl}$ & $<\mathrm{dl}$ & $<\mathrm{dl}$ & 0.32 \\
\hline $\mathrm{Tl}$ & 21 & 14.1 & 63 & 76 & 11.3 & 30 & 55 & 3.1 & 045 & 2.2 & 0.16 & $<\mathrm{dl}$ & $<\mathrm{dl}$ & 0.46 \\
\hline $\mathrm{Pb}$ & 173 & 7.1 & 455 & 554 & 110 & 148 & 497 & 31 & 24 & 159 & 4.71 & $<\mathrm{dl}$ & 24 & 0.67 \\
\hline Th & 7.4 & 3.6 & 15.2 & 19.1 & 5.7 & 10.2 & 18.9 & 4.8 & $<\mathrm{dl}$ & 29 & 2.4 & $<\mathrm{dl}$ & 6.5 & 0.04 \\
\hline $\mathrm{U}$ & 2.5 & 1.6 & 4.9 & 6 & 1.3 & 3.0 & 6.4 & 1.7 & $<\mathrm{dl}$ & 6.8 & $<\mathrm{dl}$ & $<\mathrm{dl}$ & 0.33 & 0.04 \\
\hline
\end{tabular}




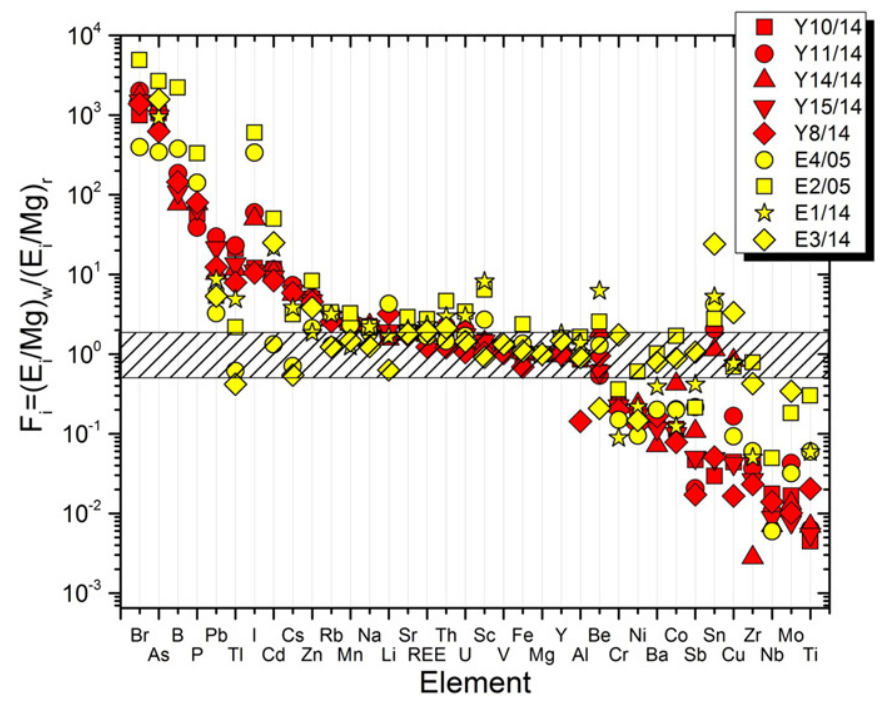

Fig. 11. Enrichment coefficients normalized to Mg for waters of Yurievskie springs and Ebeko pools. Elements within the hatched area $\left(\log \mathrm{F}_{\mathrm{i}} \sim 0\right)$ were leached from rock by congruent dissolution. See text for discussion.

\subsubsection{Solute geothermometry of Yurievskie springs}

5.2.4.1. Saturation index approach. The major cations in ultra-acidic waters of the Ebeko are present through congruent dissolution of the host rock, and thus, any cation geothermometers using $\mathrm{Na}, \mathrm{K}, \mathrm{Mg}$ and Ca are not applicable. On the other hand, water from Yurievskie springs, as many other ultra-acidic waters, are close to saturation with respect to amorphous silica (Fig. 14). Therefore, estimation of temperatures of precipitation of alumino-silicate secondary minerals using the saturation indices (SI) approach is not correct taking into account that as a rule

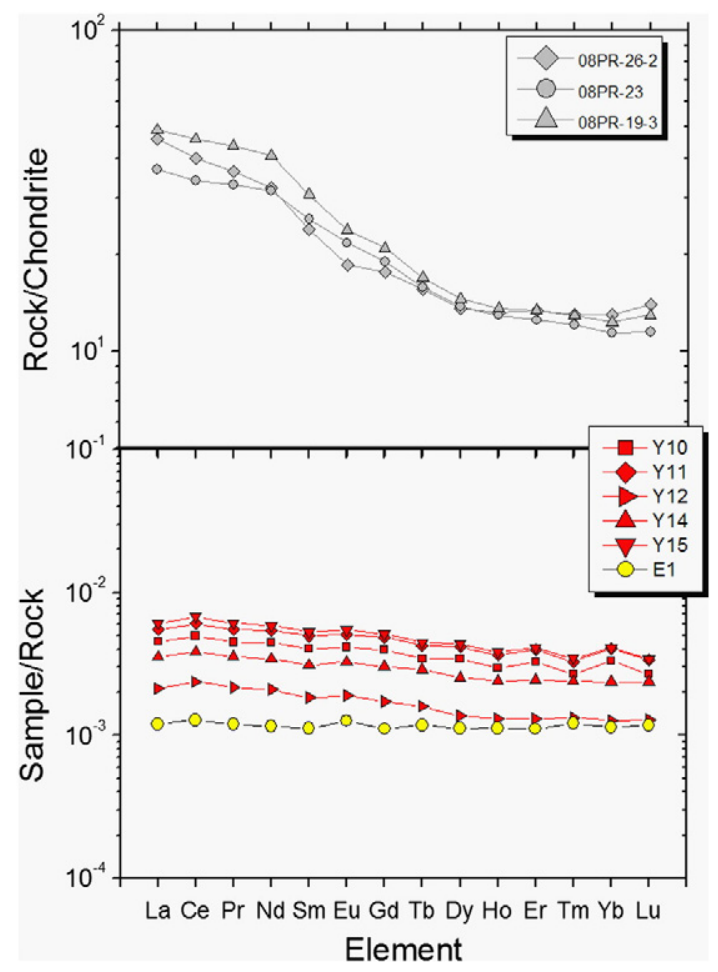

Fig. 12. REE abundance in unaltered Ebeko rocks reported by Martynov et al. (2010) normalized to chondrite (McDonough and Sun, 1995) and in Yurieva and Ebeko. All waters are normalized to the average Ebeko rock.

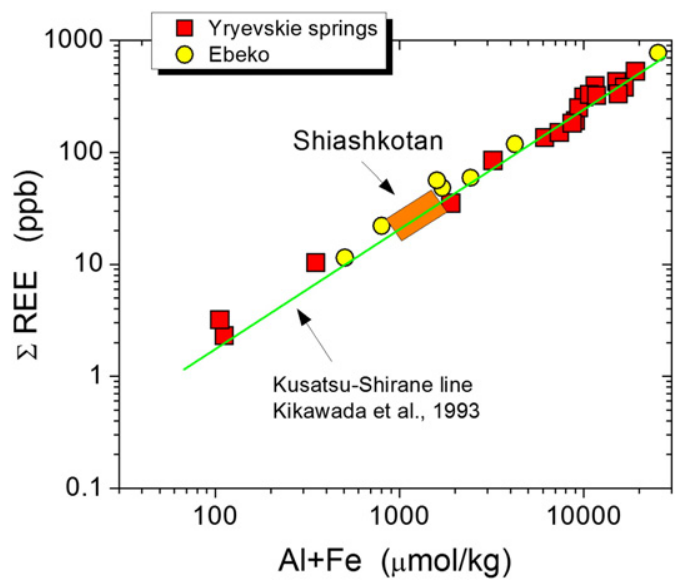

Fig. 13. Correlation between the total REE concentration and $\mathrm{Al}+\mathrm{Fe}$ molar concentration in acidic waters of Yurievskie springs and Ebeko pools. Points for Ebeko pools with lower REE concentrations are from the 2005 samples, not shown in Table 4.

the most of the SI of alumino-silicate secondary minerals show temperatures of saturation close to that of quartz. Using the SOLVEQ code (Reed and Spycher, 1984) with the updated SOLTHERM thermodynamic data base we estimated temperature of saturation for non-silicate minerals, common for the advanced argillic alteration, including diaspore, gibbsite, alunite, anhydrite, celestine and barite. Results are shown in Fig. 15 for the hottest and most mineralized Y8 (Spring 1) water. The estimated SI-temperatures (at $\log \mathrm{SI}=0$ ) for anhydrite, alunite and diaspore are between $130{ }^{\circ} \mathrm{C}$ and $200{ }^{\circ} \mathrm{C}$. Other sulfates, celestine and barite, are undersaturated in the range of temperatures. Barite approaches the saturation level at the sampling temperature.

5.2.4.2. $\mathrm{SO}_{4}-\mathrm{H}_{2} \mathrm{O}$ oxygen isotope equilibrium and sulfur isotopic composition. Kinetics of the isotopic exchange between oxygen in water and dissolved sulfate (bisulfate) depends on temperature and pH. It is fast (days-hours) in water with $\mathrm{pH}<2$ and very slow at neutral $\mathrm{pH}$ (Lloyd, 1968; Chiba and Sakai, 1985). Therefore, the isotopic equilibrium may be attained for acidic waters of Yurievskie springs with $\mathrm{pH}<2$ and the isotopic equilibrium temperature may be used to evaluate the aquifer temperatures. The hottest Spring 1 yields the isotopic equilibrium temperature of $188^{\circ} \mathrm{C}$, and other two springs $166{ }^{\circ} \mathrm{C}$ using Mizutani and Rafter (1969) (Table 5). The real temperature could be higher considering a possible reequilibration in low $\mathrm{pH}$ water during its ascent to the surface and dilution with groundwater.

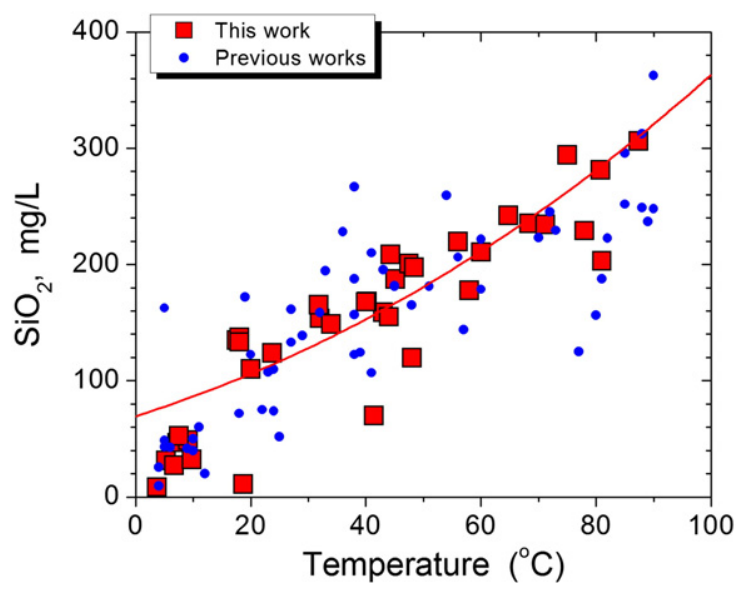

Fig. 14. Concentrations of dissolved $\mathrm{Si}$ expressed as $\mathrm{SiO}_{2}$ in Yurievskie waters vs outflow temperature. All data plot close to the solubility of amorphous $\mathrm{SiO}_{2}\left(\log \mathrm{SiO}_{2}=4.52\right.$ 731/TK; Fournier, 1977). 


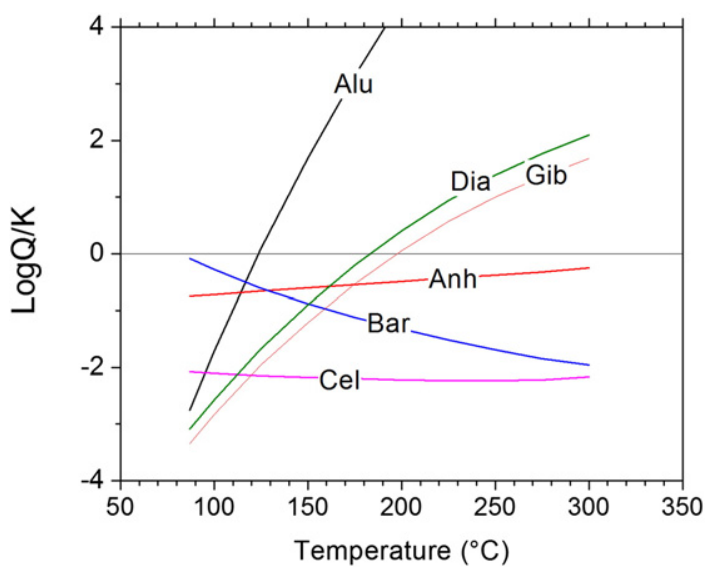

Fig. 15. Saturation indices ( $\mathrm{SI}=\log \mathrm{Q} / \mathrm{K}$, where $\mathrm{Q}$ is measured and $\mathrm{K}$ is calculated solubility product) for non-silicate minerals for the Spring 1 water. Alu-Alunite; Anh-Anhydrite; Bar-Barite; Cel-Celestine; Dia-Diaspore; Gib-Gibbsite. Computed using SOLVEQ computer code (Reed and Spycher, 1984).

Isotopic composition of $\mathrm{S}$ in $\mathrm{SO}_{4}$ is similar for all three springs and in the range of that in other ultra-acidic volcanic waters. Delmelle et al. (2000) reported values near $+22 \%$ for the Kawah Ijen crater lake, whereas Rowe (1994) showed $\delta^{34} \mathrm{~S}$ value of $+14 \%$ for an average of dissolved sulfate in Poas crater lake water. Sulfate in acidic volcanic waters can be produced by recombination of the volcanic $\mathrm{SO}_{2}$ at condensation and mixing with groundwater:

$4 \mathrm{SO}_{2}(\mathrm{aq})+4 \mathrm{H}_{2} \mathrm{O}=3 \mathrm{H}_{2} \mathrm{SO}_{4}+\mathrm{H}_{2} \mathrm{~S}(\mathrm{aq})$

or

$3 \mathrm{SO}_{2}(\mathrm{aq})+2 \mathrm{H}_{2} \mathrm{O}=2 \mathrm{H}_{2} \mathrm{SO}_{4}+\mathrm{S}_{0}$.

Assuming that these reactions are the main source of $\mathrm{SO}_{4}$ in acidic volcanic waters, the molar ratio of $\left(\mathrm{H}_{2} \mathrm{~S} / \mathrm{SO}_{2}\right), \mathrm{r}_{\mathrm{s}}$, in the condensing vapor can be estimated suggesting isotopic equilibrium between all four sulfur species: $\mathrm{SO}_{4}, \mathrm{SO}_{2}(\mathrm{aq}), \mathrm{H}_{2} \mathrm{~S}(\mathrm{aq})$ and $\mathrm{S}_{\mathrm{o}}$ and using isotopic balance (Taran et al.,1996: Kusakabe et al., 2000):

$\delta^{34} \mathrm{~S}_{\mathrm{SO} 4}=\delta^{34} \mathrm{~S}_{\mathrm{tot}}+\Delta_{\mathrm{SO} 4-\mathrm{H} 2 \mathrm{~S}} \mathrm{r}_{\mathrm{s}}\left(1+\mathrm{r}_{\mathrm{S}}\right)^{-1}+1 / 3 \Delta_{\mathrm{SO} 4-\mathrm{So}}\left(1+\mathrm{r}_{\mathrm{S}}\right)^{-1}$

where $\delta^{34} \mathrm{~S}_{\text {tot }}$ is the isotopic composition of the total dissolved sulfur and $\Delta$ are equilibrium isotope fractionation factor for the pairs of $\mathrm{SO}_{4}-$ $\mathrm{H}_{2} \mathrm{~S}$ and $\mathrm{SO}_{4}-\mathrm{S}_{\mathrm{o}}$. If one aquifer feeds low-temperature fumaroles of Ebeko and Yurievskie hot springs, we can estimate the $\mathrm{r}_{\mathrm{s}}$ ratio for the resulting gas after magmatic gas condensation in this aquifer assuming the equilibrium temperature of $200{ }^{\circ} \mathrm{C}$ (a bit higher than the temperature of the $\mathrm{SO}_{4}-\mathrm{H}_{2} \mathrm{O}$ oxygen isotopic equilibrium) using $\Delta_{\text {SO4-H2S }}=$ $31 \%$ o and $\Delta_{\text {so4-So }}=30 \%$ o (Ohmoto and Rye, 1979 ). For arc magmatic gases the isotopic composition of the total sulfur usually close to $+6 \%$ (e.g., De Hoog et al., 2001). The isotopic composition of dissolved sulfate in Yurieva waters is $+18.8 \%$. With these values the solution of the Eq. (11) is $r_{s}=0.2$, or the concentration of $\mathrm{H}_{2} \mathrm{~S}$ is significantly lower than that of $\mathrm{SO}_{2}$ in a gas at isotopic and chemical equilibrium

Table 5

Isotopic composition of oxygen in water and dissolved sulfate (\% V-SMOW) and sulfur of the sulfate $(\% \circ \mathrm{CD}), \mathrm{pH}$ and $\mathrm{SO}_{4}$ concentration in three samples from Yurievskie springs (isotopic equilibrium temperatures are calculated using calibration by Mizutani and Rafter, 1969).

\begin{tabular}{lccllll}
\hline Sample & $\delta^{18} \mathrm{O}-\mathrm{SO}_{4}$ & $\delta^{18} \mathrm{O}-\mathrm{H}_{2} \mathrm{O}$ & $\mathrm{t}^{\circ} \mathrm{C}$-isot & $\delta^{34} \mathrm{~S}^{-\mathrm{SO}_{4}}$ & $\mathrm{pH}$ & $\mathrm{SO}_{4} \mathrm{ppm}$ \\
\hline $\mathrm{Y} 8$ & -0.06 & -9.4 & 187 & 18.9 & 1.2 & 6861 \\
$\mathrm{Y} 11$ & -0.27 & -10.5 & 166 & 18.4 & 1.3 & 6182 \\
$\mathrm{Y} 14$ & 0.01 & -10.8 & 166 & 18.3 & 1.5 & 4053
\end{tabular}

among main sulfur species at $200{ }^{\circ} \mathrm{C}$. This is in agreement with the composition of the Ebeko fumaroles (Table 2) where $\mathrm{H}_{2} \mathrm{~S} / \mathrm{SO}_{2}$ as a rule is $<<1$. Thus, the temperature of Yurievskie springs, both using the saturation indices approach and the oxygen isotope composition of $\mathrm{SO}_{4}$ and $\mathrm{H}_{2} \mathrm{O}$, is calculated in the range of $150-190{ }^{\circ} \mathrm{C}$ for the aquifer feeding the springs. It can be intermediate temperature, quenched at some level between the aquifer and discharge. If the same aquifer feeds low-temperature $\mathrm{HCl}$-rich fumaroles of Ebeko, its temperature should be in the range $200-300{ }^{\circ} \mathrm{C}$ as it is shown above using gas equilibria (Fig. 5).

\section{Gas and solute fluxes}

Nekhoroshev (1960) first estimated the heat flux from the Ebeko fumaroles and reported a value of $28 \mathrm{MW}$ of the fumarolic heat output based on the measured $\approx 11 \mathrm{~kg} / \mathrm{s}$ of the output of steam emission (assuming enthalpy of $2500 \mathrm{~kJ} / \mathrm{kg}$ of steam). Menyailov et al. (1988) have measured the fumarolic flux in 1979 and 1983 and reported two similar values of $\approx 24 \mathrm{~kg} / \mathrm{s}$ of the steam output ( $\approx 60 \mathrm{MW}$ ). Our measurements in 2003 (see also Kotenko and Kotenko, 2006) yielded the steam output of $\approx 11 \mathrm{~kg} / \mathrm{s}$, which is the same as the value obtained by Nekhoroshev in 1960. Recalculation to weight percent gives an average composition of fumarolic steam for the most powerful vent of the SE field: $88.1 \mathrm{wt} \%$ $\mathrm{H}_{2} \mathrm{O}, 9.6 \mathrm{wt} \% \mathrm{CO}_{2}, 2.0 \mathrm{wt} \%$ total $\mathrm{S}\left(\mathrm{H}_{2} \mathrm{~S}+\mathrm{SO}_{2}\right)$ and $0.24 \mathrm{wt} \% \mathrm{HCl}$. Assuming that these values are representative for the total volcanic vapor output from Ebeko, daily fluxes are $\approx 840 \mathrm{t} / \mathrm{d}$ of $\mathrm{H}_{2} \mathrm{O}, 95 \mathrm{t} / \mathrm{d}$ of $\mathrm{CO}_{2}, 19 \mathrm{t} / \mathrm{d}$ of $\mathrm{SO}_{2}+\mathrm{H}_{2} \mathrm{~S}$ and $2.2 \mathrm{t} / \mathrm{d}$ of $\mathrm{HCl}$. Taking into account the uncertainty in the measured flow rates and scatters in the gas composition, the uncertainty in the estimate is probably not less than $100 \%$. Selected data on fumarolic fluxes over time are shown in Table 6.

The 2005 measurements have been conducted after a series of phreatic explosion and the formation of a new short-lived "July Field" with fumarolic temperatures up to $460{ }^{\circ} \mathrm{C}$ with a high $\mathrm{SO}_{2}$ and $\mathrm{HCl}$ content (Kotenko and Kotenko, 2006). The estimated fluxes in April, 2009 within the last phreatic cycle, based on the comparison method (areas of the fumarolic plumes on photo images) and the average composition of fumaroles of the SE field, were similar to those measured in 2005. Finally, the last 2012 measurements during a period of the steady-state passive degassing, gave estimations close to the data of Menyailov et al. (1988). Therefore, the main gas flux during this long passive degassing period is lower than $20 \mathrm{t} / \mathrm{d}$ for $\left(\mathrm{SO}_{2}+\mathrm{H}_{2} \mathrm{~S}\right)$ and $5 \mathrm{t} / \mathrm{d}$ for $\mathrm{HCl}$, although this period includes short phreatic activity.

The Yurieva River collects all Yurievskie thermal waters and flows into the Sea of Okhotsk with a measured flow rate of $1.5 \pm$ $0.3 \mathrm{~m}^{3} /$ sand contains $632 \mathrm{mg} / \mathrm{L}$ of chloride and $1715 \mathrm{mg} / \mathrm{L}$ of sulfate at the mouth of the river. The data provides the fluxes of the dissolved chloride and sulfate $82 \mathrm{t} / \mathrm{d}$ and $222 \mathrm{t} / \mathrm{d}$, respectively. The amount of sulfate is equivalent to $148 \mathrm{t} / \mathrm{d}$ of the $\mathrm{SO}_{2}$ flux. Comparing to the gas fluxes from Ebeko fumaroles $(<5 \mathrm{t} / \mathrm{d}$ of $\mathrm{HCl}$ and $<20 \mathrm{t} / \mathrm{d}$ of $\mathrm{SO}_{2}+\mathrm{H}_{2} \mathrm{~S}$ ) the hydrothermal flux from thermal springs is much greater. The estimated hydrothermal flux (we believe that the uncertainty is not higher than $30 \%$ ), is similar to the measured gas fluxes using remote techniques volcanic gas fluxes from many passively degassing volcanoes hosting high-temperature fumarolic fields

Table 6

Fumarolic output of $\mathrm{H}_{2} \mathrm{O}, \mathrm{CO}_{2}, \mathrm{SO}_{2}+\mathrm{H}_{2} \mathrm{~S}$ and $\mathrm{HCl}(\mathrm{t} / \mathrm{d}$ ) and heat output (MW) from Ebeko fumarolic fields. nd-not determined.

\begin{tabular}{lllllll}
\hline Year & $1960^{\mathrm{a}}$ & $1983^{\mathrm{b}}$ & $2003^{\mathrm{c}}$ & $2005^{\mathrm{c}}$ & $2009^{\mathrm{c}}$ & $2012^{\mathrm{c}}$ \\
\hline $\mathrm{H}_{2} \mathrm{O}$ & 864 & 1804 & 840 & 7593 & 6767 & 1864 \\
$\mathrm{CO}_{2}$ & nd & 79 & 95 & 448 & 219 & 185 \\
$\mathrm{SO}_{2}+\mathrm{H}_{2} \mathrm{~S}$ & nd & 13.3 & 19 & 933 & 71 & 19 \\
$\mathrm{HCl}$ & nd & 3.8 & 2.2 & 418 & 13 & 5 \\
\hline
\end{tabular}

a Nekhoroshev (1960).

b Menyailov et al. (1988).

c Kotenko et al. (2012) and this work. 
(Vulcano, Kudryavy, Mutnovsky, etc., see Taran, 2009, and references therein). Even greater fluxes from Yurievskie springs have been reported by Zelenov in 1957 (Zelenov, 1972) and Shilov in 1960 (cited by Markhinin and Stratula, 1977). At those times the vent temperature of Spring 1 was near boiling. During the period from 1984 to 2014 the Spring 1 temperature varied between 78 and $87^{\circ} \mathrm{C}$ and the flux of $\mathrm{Cl}$ ranged from 62 to $98 \mathrm{t} / \mathrm{d}$ for chlorine. These fluxes $\left(\mathrm{Cl}\right.$ and $\left.\mathrm{SO}_{4}\right)$ from Ebeko-Yurieva are much greater than those from other hydrothermal systems of the Kamchatka-Kuril subduction zone (Taran, 2009). The fluxes are even much greater than that from other acidic volcanohydrothermal systems in the world (Table 7) and comparable with those of giant meteoric-hydrothermal system at Yellowstone and Domuyo (Hurwitz et al., 2007, 2010; Chiodini et al., 2014).

\section{Conceptual model of the Ebeko-Yurievskie volcano-hydrothermal system}

High $\mathrm{HCl}$ concentrations in low-temperature fumaroles and low relative concentrations of $\mathrm{H}_{2}$ and $\mathrm{CO}$ in volcanic gases are attributed for the presence of a boiling aquifer beneath the summit area of Ebeko. This aqueous solution should be highly saline and hyper-acidic. Gas and solute equilibria suggest that the aquifer temperature is probably not less than $200{ }^{\circ} \mathrm{C}\left(\sim 250{ }^{\circ} \mathrm{C}\right.$ from the fumarolic gas geothermometry and $\leq 200^{\circ} \mathrm{C}$ from solute and isotope geothermometry of Yurievskie waters). The curve of boiling-points at various depths by Ellis and Mahon (1977) shows that water at $250^{\circ} \mathrm{C}$ boils at $\sim 300 \mathrm{~m}$. This aquifer appears to be in "steady-state" balanced by the in-flux of magmatic fluid from depth and meteoric water from the surface and an outflow as fumarolic vapors and drainage to Yurievskie springs. The system is similar to other areas where acidic water represents crater lakes and associated shallow aquifers. Examples include those at Poas, Copahue, Kawah Ijen (Rowe et al., 1992; Varekamp et al., 2001; Delmelle et al., 2000). In the case of Ebeko, the acidic water is concealed at a considerable depth. Temperature of fumaroles of Ebeko is controlled by the two-phase steam-water mixture above the aquifer. The temperature is higher than the boiling point of pure water at the elevation of the fumarolic field due to high concentration of solutes. The mechanism causing phreatic eruptions at Ebeko is probably similar to that at Poas volcano where hot gases suddenly ascend through ruptured seals (Fischer et al., 2015; Rouwet and Morrissey, 2015). When the pressure of hot gases drops and the fractures are filled again by the two-phase boiling fluid, temperature of fumaroles re-establish at the stationary level.

Assuming that one aquifer feeds $\mathrm{Cl}$ and sulfur to fumaroles, an equivalent amount of $\mathrm{CO}_{2}$ for the $\mathrm{Cl}$ flux from Yurievskie springs should come out through the volcano edifice. With the $\mathrm{CO}_{2} / \mathrm{S}$ weight ratio in Ebeko

Table 7

Chloride and sulfur fluxes ( $\mathrm{t} / \mathrm{d}$ ) from Ebeko-Yurieva and other volcano-hydrothermal systems.

\begin{tabular}{|c|c|c|c|}
\hline $\begin{array}{l}\text { Volcano-hydrothermal } \\
\text { system, year }\end{array}$ & Chloride & $\begin{array}{l}\text { Sulfur } \\
\text { (as } \mathrm{SO}_{2} \text { ) }\end{array}$ & Reference \\
\hline \multicolumn{4}{|l|}{ Yurieva, Ebeko volcano } \\
\hline 1957 & 222 & 448 & Markhinin and Stratula (1977) \\
\hline 1960 & 264 & 443 & -“- - n \\
\hline 1984 & 62 & 106 & Fazlullin (1999) \\
\hline 1987 & 76 & 127 & $-“-$ \\
\hline 2013 & 98 & 120 & Bortnikova et al. (2006) \\
\hline 2014 & 82 & 148 & This work \\
\hline \multicolumn{4}{|c|}{ Other volcano-hydrothermal systems } \\
\hline Shiashkotan (Kurils), 2011 & 27 & 70 & Kalacheva et al. (2015) \\
\hline Poas, 1990 & 35 & 60 & Rowe et al. (1992) \\
\hline El Chichon, 2008 & 42 & 5 & Taran and Peiffer (2009) \\
\hline Copahue, 2001-2004 & 38 & 135 & Varekamp et al. (2001) \\
\hline Domuyo, 2010 & 160 & & Chiodini et al. (2014) \\
\hline Yellowstone, 1986-2007 & 140 & 150 & $\begin{array}{l}\text { Fournier (1989), Hurwitz et al. } \\
\text { (2007) }\end{array}$ \\
\hline
\end{tabular}

fumaroles close to 6 the diffusive and advective flux of $\mathrm{CO}_{2}$ through the edifice should be $600-800 \mathrm{t} / \mathrm{d}$.

\section{Conclusions}

Ultra-acidic volcano-hydrothermal system of the Ebeko volcanic massive discharges both fumarolic gases and hyper-acid waters near the summit of Ebeko volcano and ultra-acid hot waters of the Yurievskie springs on the western slope. The spring waters are drained by Yurieva River which flows to the Sea of Okhotsk.

Ebeko low-temperature fumaroles are enriched in $\mathrm{HCl}$ (up to $0.3 \mathrm{~mol} \%$ ) which is attributed to boiling of a hyper-acid brine at 250$300 \mathrm{~m}$ depth below the summit at temperature of $250-300^{\circ} \mathrm{C}$. The existence of a two-phase, liquid-water aquifer is also supported by redox-equilibria in the $\mathrm{H}_{2} \mathrm{O}-\mathrm{H}_{2}-\mathrm{CO}-\mathrm{CO}_{2}-\mathrm{CH}_{4}$ system, temperature estimates based on saturation indices of Yurieva spring waters for some non-silicate minerals, and the oxygen isotope equilibrium temperatures of water and sulfate.

Major and trace element composition (including REE) of EbekoYurievskie acidic waters is similar to compositions of other ultra-acidic volcanic waters (crater lakes) elsewhere in the world suggesting congruent dissolution of volcanic rocks. The ${ }^{86} \mathrm{Sr} /{ }^{87} \mathrm{Sr}$ values of $0.70315-$ 0.70316 for dissolved $\mathrm{Sr}$ are similar to those for Ebeko andesites.

The fluxes of chlorine and sulfur ( $\mathrm{as} \mathrm{SO}_{2}$ ) from the fumaroles in the summit area $(<5 \mathrm{t} / \mathrm{d}$ and $<20 \mathrm{t} / \mathrm{d}$, respectively) are almost one order of magnitude lower than the fluxes from the Yurievskie springs along the Yurieva River. The total outputs from thermal fields of Ebeko volcano are among the highest ever measured in the world.

The Ebeko-Yurievskie volcano-hydrothermal system is similar to those for ultra-acidic crater lakes such as Poas and Copahue. Unlike crater lakes, the thermal manifestations at Ebeko-Yurievskie is fed by a shallow aquifer below the surface.

\section{Acknowledgments}

This work was supported by a Russian Science Foundation grant \# 15-17-20011. We thank Edith Cienfuegos and Ruben Bernard for chemical and isotopic analyses of water samples. Thanks to G. Arrieta García and T. Hernández Treviño for their help with the Sr isotope analysis. Detailed reviews by $\mathrm{S}$. Calabrese and F. Tassi are greatly appreciated.

\section{References}

Alvarez, J., Corti, H.R., Fernandea-Prin, R., Japas, M.L., 1994. Distribution of solutes between coexisting steam and water. Geochim. Cosmochim. Acta 58, 2789-2798.

Avdeiko, G.P., Antonov, A.Y., Volynets, O.N., 1992. Submarine Volcanism and Zoning of the Kuril Island Arc. Nauka, Moscow (528 pp. in Russian).

Bessonova, E.P., Bortnikova, S.B., Bessonov, D.Y., Khramov, A.A., 2006. Hydrogeochemistry of thermal fields associated with the Ebeko system. Hydrogeology and Geochemistry of Waters of Siberia and Far East. Proceedings of the conference, Vladivostok (98-107 pp. in Russian).

Bortnikova, S.B., Bessonova, E.P., Trofimova, L.B., Kotenko, T.A., Nikolayeva, N.V., 2006 Hydrogeochemistry of thermal springs of Ebeko volcano (Paramushir Island). Vulcanol. Seismol. 1, 39-51 (in Russian).

Chiba, H., Sakai, S., 1985. Oxygen isotope exchange rate between dissolved sulfate and water at hydrothermal temperatures. Geochim. Cosmochim. Acta 43, 993-1000.

Chiodini, G., Liccioli, C., Vaselli, O., Calabrese, S., Tassi, F., Caliro, S., D'Alessandro, W., 2014 The Domuyo volcanic system: an enormous geothermal resource in Argentine Patagonia. J. Volcanol. Geotherm. Res. 274, 71-77.

Christenson, B.W., Wood, C.P., 1993. Evolution of a vent-hosted hydrothermal system beneath Ruapehu Crater Lake, New Zealand. Bull. Volcanol. 55, 547-565.

De Hoog, J.C.M., Taylor, B.E., van Bergen, M.J., 2001. Sulfur isotope systematics of basalts from Indonesia: implications for the sulfur cycle in subduction zones. Earth Planet Sci. Lett. 189, 237-252.

Delmelle, P., Bernard, A., Kusakabe, M., Fischer, T., Takano, B., 2000. Geochemistry of magmatic-hydrothermal system of Kawah Ijen volcano, East Java, Indonesia. J. Volcanol. Geotherm. Res. 97, 31-53.

Driesner, T., Seward, T.M., 2000. Experimental and simulation study of salt effects and pressure/density effects on oxygen and hydrogen stable isotope liquid-vapor fractionation for $4-5$ molar aqueous $\mathrm{NaCl}$ and $\mathrm{KCl}$ solutions to $400{ }^{\circ} \mathrm{C}$. Geochim. Cosmochim. Acta 64, 1773-1784.

Ellis, A.J., Mahon, W.A.J., 1977. Chemistry and Geothermal Systems. Fcad. Press, NY (392 pp.). 
Fazlullin, S.M., 1999. Geochemical system of Yurieva River (Kuril Islands); conditions of the addition and discharge of the elements for the drainage basin. Vulcanol. Seismol. 1, 54-68 (in Russian).

Fedorchenko, V.I., Abdurakhmanov, A.I., Rodionova, R.I., 1989. Volcanism of the Kurile Island Arc: Geology and Petrogenesis. Nauka, Moscow (237 pp. in Russian).

Fischer, T.P., Ramirez, C., Mora-Amador, R., Hilton, D.R., Barnes, J.D., Sharp, Z.D., Le Brune, M., de Moor, J.M., Furi, E., Shaw, A.M., 2015. Temporal variations in fumaroles gas chemistry at Poas volcano, Costa Rica. J. Volcanol. Geotherm. Res. 294, $56-70$.

Fournier, R.O., 1977. Chemical geothermometers and mixing models for geothermal systems. Geothermics 5 (1), 41-50.

Fournier, R.O., 1989. Geochemistry and dynamics of the Yellowstone National Park hydrothermal system. Annu. Rev. Earth Planet. Sci. 17, 13-53.

Giggenbach, W.F., 1974. The chemistry of crater lake, Mt. Ruapehu (New Zealand) during and after the 1971 active period. N. Z. J. Sci. 17, 33-45.

Giggenbach, W.F., 1987. Redox processes governing the chemistry of fumarolic gas discharges from White Island, New Zealand. Appl. Geochem. 2, 143-161.

Giggenbach, W.F., 1992. Isotopic shifts in waters from geothermal and volcanic systems along convergent plate boundaries and their origin. Earth Planet. Sci. Lett. 113, 495-510.

Giggenbach, W.F., Goguel, R.L., 1989. Collection and analysis of geothermal and volcanic water and gas discharges. New Zealand DSIR Chem. Division Report 2407, Christchurch, New Zealand (88 pp.).

Gorshkov, G.S., 1970. Volcanism of the Upper Mantle: Investigations in the Kuril Island Arc. Plenum Press, NY (385 pp.).

Hilton, D.R., Fischer, T.P., Marty, B., 2002. Noble gases and volatile recycling at subduction zones. Noble gases in cosmochemistry and geochemistry. Miner. Soc. Am. vol. 47, pp. 319-370.

Horita, J., Wesolowski, D.J., 1994. Liquid-vapor fractionation of oxygen and hydrogen isotopes of water from the freezing to the critical temperature. Geochim. Cosmochim. Acta 58, 3425-3437.

Hurwitz, S., Lowenstern, J., Heasler, H., 2007. Spatial and temporal geochemical trends in the hydrothermal system of Yellowstone National Park; interferences from river solute fluxes. J. Volcanol. Geotherm. Res. 162, 149-171.

Hurwitz, S., Ewans, W., Lowenstern, J., 2010. River solute flux reflecting active hydrothermal chemical weathering of the Yellowstone Plateau volcanic field, USA. Chem. Geol. 276, 331-343.

Ivanov, V.V., 1961. Geological conditions and geochemical processes of the formation of thermal waters in areas of the modern volcanism. Tr. Lab. Vulkanol. Acad. Sci. USSR $19,156-178$ (in Russian).

Kalacheva, E.G., Kotenko, T.A., 2013. Chemical composition and the origin of the Upper Yurievskie thermal springs (Paramushir, Kuril Islands). Vestn. KRAUNTS 2 (22), 55-68 (in Russian).

Kalacheva, E., Taran, Y., Kotenko, T., 2015. Geochemistry and solute fluxes of volcano-hydrothermal systems of Shiashkotan, Kuril Islands. J. Volcanol. Geotherm. Res. 296, 40-54.

Kelemen, P.B., Hanghet, K., Greene, A.R., 2007. One View on the Geochemistry of Subduction-Related Magmatic Arcs With an Emphasis on Primitive Andesites and Lower Crust, 2nd edition Treatites on Geochemistry vol. 3. Elsevier, pp. 1-72.

Kikawada, Y., Oi, T., Honda, T., Osaka, T., Kakihana, H., 1993. Lanthanoid abundances of acidic hot spring and crater lake waters in the Kusatsu-Shirane volcano region, Japan. Geochem. J. 27, 19-33.

Kotenko, T.A., Kotenko, L.V., 2006. Hydrothermal manifestations and heat flux of volcanoes Ebeko and Krasheninnikov (Paramushir, Kuril Islands). Vestn. KRAUNTS 1 (7), 129-137 (in Russian).

Kotenko, T.A., Kotenko, L.V., Shapar, V.N., 2007. Activation of Ebeko volcano in 2005-2006 (Paramushir, Kuril Islands). Vulcanol. Seismol. 5, 3-14 (in Russian).

Kotenko, T.A., Kotenko, L.V., Sandimirova, E.I., Shapar, V.N., Timofeeva, I.F., 2012. Eruption activity of Ebeko volcano (Paramushir i.) in 2010-2011. Vestn. KRAUNTS 1 (19), 160-167 (in Russian)

Kusakabe, M., Komoda, Y., Takano, B., Abiko, T., 2000. Sulfur isotopic effects in the disproportionation reaction of sulfur dioxide in hydrothermal fluids and the variation of $34 \mathrm{~S}$ values of dissolved bisulfate and elemental sulfur from some active crater lakes. J. Volcanol. Geotherm. Res. 97 (1-4), 287-307.

Lloyd, R.M., 1968. Oxygen isotope behavior in the sulfate-water system. J. Geophys. Res. 73, 61-6099.

Markhinin, E.K., 1967. Role of Volcanism in the Formation of the Earth Crust. Nauka Moscow (267 pp. in Russian).

Markhinin, E.K., Stratula, D.S., 1977. Hydrothermal Systems of Kuril Islands. Nauka, Moscow (227 pp. in Russian).

Martynov, Yu.A., Khanchuk, A.I., Kimura, J.I., Rybin, A.V., Martynov, A.Yu., 2010. Geochemistry and petrogenesis of volcanic rocks in the Kuril island. Petrologiya 18, 512-535 (in Russian).

McDonough, W.F., Sun, S.-S., 1995. The composition of the Earth. Chem. Geol. 120, 223-253.

Melekestsev, I.V., Dvigalo, V.N., Kirianov, V.Y., et al., 1993. Ebeko volcano (Kuril Islands): history of the eruptive activity and a future volcanic hazard. Vulcanol. Seismol. 3 69-81 (in Russian).

Menyailov, I.A., Nikitina, L.P., Shapar, V.N., 1985. Results of geochemical monitoring of the activity of Ebeko volcano (Kuril Islands) used for the eruption prediction. J. Geodyn. 3, 259-274.

Menyailov, I.A., Nikitina, L.P., Shapar, V.N., 1988. On the chemical and isotopic composition of fumarolic gases of Ebeko volcano between eruptions. Vulcanol. Seismol. 4 21-36 (in Russian).

Menyailov, I.A., Nikitina, L.P., Budnikov, V.A., 1992. Activity of Ebeko volcano from 1987 to 1991; character of eruptions, eruptive products and volcanic hazard. Vulcanol Seismol. 5-6, 21-33 (in Russian).
Mizutani, Y., Rafter, A.T., 1969. Oxygen isotopic fractionation in the bisulfate ion-water system. N. Z. J. Sci. 12, 54-59.

Nekhoroshev, A.S., 1960. Geothermal conditions and heat flux of Ebeko volcano on Paramushir Island. Bull. Volcanol. Stantsii 29, 38-46 (in Russian).

Newsletter, 2006. Neswsletter of the IAVCEI Comission on the Chemistry of Volcanic Gases, \# 19. In: Taran, Y., Fischer, T. (Eds.), Evaluation of Results.

Nikitina, L.P., 1978. Migration of Metals from Active Volcanoes to Sedimentary Basin. Nauka, Moscow (80 pp. in Russian).

Ohmoto, H., Rye, R.O., 1979. Isotopes of sulfur and carbon. In: Barnes, H.L. (Ed.), Geochemistry of Hydrothermal Ore Deposits. Wiley, New York, pp. 509-567.

Palmer, D.A., Simonson, J.M., Jensen, J.P., 2004. Partitioning of electrolites to steam and their solubilities in steam. In: Fernandez-Pinti, F., Harvey, A., Palmer, D.A. (Eds.), Aqueous Systems at Elevated Temperatures and Pressures. Elsevier, pp. 409-440.

Pasternack, G.B., Varekamp, J.C., 1994. The geochemistry of the Keli Mutu crater lakes, Flores, Indonesia. Geochem. J. 28, 243-262.

Peiffer, L., Taran, Y., Lounejeva, E., Solís-Pichardo, G., Rouwet, D., Bernard-Romero, R., 2011. Tracing thermal aquifers of El Chichon volcano-hydrothermal system (Mexico) with ${ }^{87} \mathrm{Sr} /{ }^{86} \mathrm{Sr}, \mathrm{Ca} / \mathrm{Sr}$ and REE. J. Volcanol. Geotherm. Res. 205, 55-66.

Reed, M.H., Spycher, N.F., 1984. Calculation of pH and mineral equilibria in hydrothermal waters with application to geothermometry and studies of boiling and dilution. Geochim. Cosmochim. Acta 48, 1479-1492.

Roine, A., 2009. HSC Chemistry. www.outotec.com.

Rouwet, D., Morrissey, M.M., 2015. Mechanisms of crater lake breaching eruptions. In: Rouwet, D., et al. (Eds.), Volcanic Lakes. Advances in Volcanology. Springer-Verlag, Berlin, pp. 73-91.

Rowe, G.L., 1994. Oxygen, hydrogen, and sulfur isotope systematics of the crater lake system of Poa's volcano, Costa Rica. Geochem. J. 28, 263-287.

Rowe, G.L., Brantley, S.L., Fernandez, M., Fernandez, J.F., Barquero, J., Borgia, A., 1992. Fluid-volcano interaction in an active stratovolcano: the crater lake system of Poas volcano, Costa Rica. J. Volcanol. Geotherm. Res. 49, 23-51.

Rozhkov, A.M., Verkhovsky, A.B., 1990. Geochemistry of Noble Gases in High Temperature Hydrothermal Systems. Nauka, Moscow (167 pp. in Russian).

Rychagov, S.N., Belousov, V.I., Glavatskikh, G.F., Ladygin, V.M., Sefafimova, E.K., 2002. The North Paramushir magmatic-hydrothermal system: the deep geologic section and a model of the present day mineralization and metallization in the interior of the system. Vulcanol. Seismol. 4, 3-21 (in Russian).

Sanada, T., Takamatsu, N., Yoshiike, Y., 2006. Geochemical interpretation of long-term variations in rare earth element concentrations in acidic hot spring water from the Yamagawa geothermal area, Japan. Geothermics 35, 141-155.

Schaaf, P., Stimac, J., Siebe, C., Macías, J.L., 2005. Geochemical evidence for mantle origin and crustal processes in volcanic rocks from Popocatépetl and surrounding monogenetic volcanoes, central Mexico. J. Petrol. 46, 1243-1282.

Schmulovich, K.I., Landwehr, D., Simon, K., Heinrich, W., 1999. Stable isotope fractionation between liquid and vapor in water-salt system. Chem. Geol. 157, 343-354.

Sergeev, K.F., 1966. Geological Structure and Evolution of the Northern Kuril Islands. Nauka, Moscow (167 pp. in Russian).

Shinohara, H., 2013. Volatile flux from subduction zone volcanoes: Insights from a detailed evaluation of the fluxes from volcanoes in Japan. J. Volcanol. Geotherm. Res. 268, 46-63.

Shinohara, H., Giggenbach, W.F., Kazahaya, K., Hedenquist, J.W., 1993. Geochemistry of volcanic gases and hot springs of Satsuma Iwojima, Japan. Geochem. J. 27, 271-285.

Sidorov, S.S., 1965. Geochemistry of hydrothermal systems of Kuril Islands (PhD Thesis) Institute of Volcanology (in Russian).

Simonson, J.M., Palmer, D.A., 1993. Liquid-vapor partitioning of $\mathrm{HCl}(\mathrm{aq})$ to $350{ }^{\circ} \mathrm{C}$. Geochim. Cosmochim. Acta 57, 1-7.

Tagirov, B.R., Zotov, A.V., Akinfiev, N.N., 1997. Experimental study of dissociation of $\mathrm{HCl}$ from 350 to $500{ }^{\circ} \mathrm{C}$ and from 500 to 2500 bars: thermodynamic properties of $\mathrm{HCl}^{\circ}$ (aq). Geochim. Cosmochim. Acta 61, 4267-4280.

Taran, Y.A., 2005. A method for determination of the gas-water ratio in bubbling springs. Geophys. Res. Lett. 32, L23403. http://dx.doi.org/10.1029/2005GL024547.

Taran, Y.A., 2009. Geochemistry of volcanic and hydrothermal fluids and volatile budget of the Kamchatka-Kuril subduction zone. Geochim. Cosmochim. Acta 73, 1067-1094.

Taran, Y.A., Peiffer, L., 2009. Hydrology, hydrochemistry and geothermal potential of El Chichon volcano-hydrothermal system, Mexico. Geothermics 38, 370-378.

Taran, Y., Zelenski, M., 2014. Systematics of water isotopic composition and chlorine content in arc-volcanic gases. In: Zellmer, G.F., Edmonds, M., Straub, S.M. (Eds.), The Role of Volatiles in the Genesis, Evolution and Eruption of Arc Magmas. Geological Society, London, Special Publications, pp. 410-432.

Taran, Y.A., Pokrovsky, B.G., Doubik, Y.M., 1989. Isotopic composition and origin of water in andesitic magmas. Dokl. Earth Sci. 304, 1191-1194.

Taran, Y.A., Znamensky, V.S., Yurova, L.M., 1996. A geochemical model of the hydrothermal systems of Baransky volcano, Iturup, Kuril Islands. J. Volcanol. Seismol. 17, 471-496.

Taran, Y., Rouwet, D., Inguaggiato, S., Aiuppa, A., 2008. Major and trace element geochemistry of neutral and acidic thermal springs at El Chichon volcano. Mexico: implications for monitoring of the volcanic activity. J. Volcanol. Geotherm. Res. 178, 224-236.

Varekamp, J.C., Ouimette, A.P., Herman, S.W., Bermudez, A., Delpino, D., 2001. Hydrothermal element fluxes from Copahue, Argentina: a "beehive" volcano in turmoil. Geology $29,1059-1062$.

Vaselli, O., Tassi, F., Minissali, A., Montegrossi, G., Duarte, R., Fernandez, E., Bergamaschi, F., 2003. Fumarole migration and fluid geochemistry at Poas volcano, (Costa Rica) from 1998 to 2001. In: Oppenheimer, C., Pyle, D.M., Barclay, I. (Eds.), Volcanic Degassing. Geol. Soc. London, Spec. Publications 213, pp. 247-262.

Zelenov, K.K., 1972. Volcanoes as a Source of the Ore-Forming Components in Sedimentary Strata, 1972. Nauka, Moscow (230 pp. in Russian). 